\title{
Comparison of Iodide, Iodate, and Iodine-Chitosan Complexes for the Biofortification of Lettuce
}

\author{
Irma Esther Dávila Rangel ${ }^{1}{ }^{(0}$, Libia Iris Trejo Téllez ${ }^{2}$, Hortensia Ortega Ortiz ${ }^{3}$, \\ Antonio Juárez Maldonado ${ }^{4}$ (), Susana González Morales ${ }^{5}{ }^{(D}$, \\ Barbarita Companioni González ${ }^{1}$ (D), Marcelino Cabrera De la Fuente ${ }^{1}$ and \\ Adalberto Benavides Mendoza ${ }^{1, *(\mathbb{D})}$ \\ 1 Department of Horticulture, Universidad Autónoma Agraria Antonio Narro, Saltillo, Coahuila 25315, \\ Mexico; idavilarangel@gmail.com (I.E.D.R.); bcompanioni2007@gmail.com (B.C.G.); \\ cafum7@yahoo.com (M.C.D.1.F.) \\ 2 Soil Science-Plant Nutrition, Colegio de Postgraduados Campus Montecillo, Carretera México-Texcoco km \\ 36.5, Montecillo, Texcoco, Estado de México 562330, Mexico; tlibia@colpos.mx \\ 3 Department of Advanced Materials, Centro de Investigación en Química Aplicada, Saltillo, Coahuila 25294, \\ Mexico; hortensia.ortega@ciqa.edu.mx \\ 4 Department of Botany, Universidad Autónoma Agraria Antonio Narro, Saltillo 25315, Mexico; \\ juma841025@hotmail.com \\ 5 CONACYT-UAAAN, Universidad Autónoma Agraria Antonio Narro, Saltillo 25315, Mexico; \\ sgonzalezmo@conacyt.mx \\ * Correspondence: abenmen@gmail.com; Tel.: +52-844-411-0303
}

Received: 24 February 2020; Accepted: 27 March 2020; Published: 31 March 2020

Featured Application: Use of Cs-I complexes as material to biofortify soilless crops with iodine. under conditions of protected agriculture.

\begin{abstract}
Iodine is an essential trace nutrient for humans; its deficit can affect motor and cognitive development. Biofortifying crops with iodine is a way of promoting the adequate intake of this element. The uses of chitosan-iodine complexes for crop biofortification have not been previously studied. The present work evaluated the effects of $\mathrm{KIO}_{3}$ and $\mathrm{KI}$ salts, chitosan- $\mathrm{KIO}_{3}$ complex $\left(\mathrm{Cs}-\mathrm{KIO}_{3}\right)$, and chitosan-KI complex (Cs-KI) application on lettuce, with a chitosan-only treatment as a control and water as the absolute control. Each treatment involved the application of 0,5, and $25 \mathrm{mg} \mathrm{I} \mathrm{kg}^{-1}$ soil applied before transplanting or $25 \mathrm{mg} \mathrm{I} \mathrm{kg}^{-1}$ soil applied as split doses of $12.5 \mathrm{mg} \mathrm{kg}^{-1}$, once immediately before transplanting and the second application 15 days later. Single application of $\mathrm{Cs}^{-} \mathrm{KIO}_{3}$ at 5 and $25 \mathrm{mg} \mathrm{I} \mathrm{kg}^{-1}$ increased lettuce biomass while the split-dose application (SDA) of Cs-KI ( $25 \mathrm{mg} \mathrm{I} \mathrm{kg}^{-1}$ ) led to a decrease in biomass. Maximum accumulation of iodine in lettuce was observed after the application of $\mathrm{KIO}_{3}\left(25 \mathrm{mg} \mathrm{I} \mathrm{kg}^{-1}\right)$ in two parts. This study shows that the use of chitosan complexes, especially $\mathrm{Cs}-\mathrm{KIO}_{3}$, may be a viable alternative for crop biofortification with iodine without affecting crop yields.
\end{abstract}

Keywords: trace element; biopolymer; iodine; complex; biofortification

\section{Introduction}

Iodine is an essential trace element for humans. Iodine deficit can cause iodine deficiency disorders (IDD), which, according to some estimates, affect around two billion people [1]. Recommended daily iodine intake levels are $90 \mu \mathrm{g}$ for preschool children (0 to 59 months), $120 \mu \mathrm{g}$ for children 6 to 12 years old, $150 \mu \mathrm{g}$ for adults over 12 years old, and $200 \mu \mathrm{g}$ for pregnant and nursing women, according to the World Health Organization (WHO), the United Nations Children's Fund (UNICEF), and the 
International Council for Control of Iodine Deficiency Disorders (ICCIDD) [2]. Some experts believe that doses of 1-2 mg per day are probably safe for most people, although not all [3,4]. A worldwide initiative in 1920 led to the universal iodization of table salt, which led to a significant increase in iodine intake. Unfortunately, inorganic iodine salts have a disadvantage in that up to $20 \%$ can be lost through volatilization, on top of the percentages that are lost depending on the type of cooking used [5-7]. The WHO recommends that salt consumption not surpass more than $5 \mathrm{~g}$ per day, equivalent to $>2 \mathrm{~g}$ of sodium per day, as high salt intake combined with insufficient potassium intake ( $<3.5 \mathrm{~g}$ per day) can provoke high blood pressure. Because of that, the WHO aims to reduce salt intake by $30 \%$ in the worlds' population by 2025 [8]. Thus, alternative options for adequate iodine intake while reducing salt consumption are necessary.

The iodine supplementation of foods or the biofortification of plant-based foods would be one alternative for maintaining iodine intake while reducing table salt consumption. The advantage of biofortification is that the iodine is found in organic forms that have greater bioavailability and stability against volatilization than the inorganic salt forms. Another advantage of biofortification is that it can be applied to frequently consumed or traditional crops in certain regions [9].

Iodine is not considered an essential nutrient for terrestrial plants; however, it plays an important part of algae metabolism [9]. The chemical forms of iodine most commonly used for crop biofortification are potassium iodide and potassium iodate. In lettuce, biofortification with different doses of iodide $\left(\mathrm{I}^{-}\right)$ and iodate $\left(\mathrm{IO}_{3}{ }^{-}\right)$cause changes in biomass, enzymatic activity, and antioxidant activity, suggesting they might cause toxicity in plants [10-14]. The type of iodine application, either sprayed on the foliage or applied directly to the growth substrate or soil, can affect the final concentrations of iodine in the edible parts of the plants. Some studies have found foliar iodine applications to be more effective than soil applications $[11,15]$. However, foliar applications are reportedly less effective for biofortifying fruits or seeds, supposedly due to lower iodine mobility through phloem when applied via foliar spray $[9,16,17]$. When iodine is applied to soil or substrate, its bioavailability depends on the volatilization rate and its interaction with other soil components like metal oxides or hydroxides. For example, $\mathrm{Fe}(\mathrm{OH})_{3}, \mathrm{Al}(\mathrm{OH})_{3}$, and $\mathrm{MnO}_{2}$, can play an important role in the determination of iodine behavior in soil, both through inorganic iodine adsorption and iodine oxidation [18-20].

Chitosan (Cs) is a biodegradable, biological polymer that functions as a metal and trace metal complexing agent. Chitosan also possesses a wide variety of properties: it is a plant elicitor as it induces phytoalexin production; it protects plants from pathogen diseases as it inhibits microbial growth; it activates MAP-kinases and provokes chromatin alterations; and it participates in the synthesis of alkaloids and plant growth regulators. It is also biodegradable, biocompatible, induces several plant defense genes, and induces proteinase inhibitors. Responses to its application will depend on the concentration, plant species, and growth phase [21-24].

The electrostatic interactions between the amino group (positively charged; $-\mathrm{NH}_{2}$ ) and iodate (negatively charged; $-\mathrm{IO}_{3}$ ) are quite pronounced $[7,25]$. An increase in the degree of deacetylation of chitin leads to a greater complexing capacity, as that ability is related to the content of $\mathrm{NH}_{2}$ [26]. To date, the exact mechanism by which the rhizosphere operates with the chitosan-iodine complexes is unknown. Iodide or iodate ions can be absorbed by the roots because they are bound to Cs only by electrostatic interactions that are weak [27]. It is possible that exchange reactions occur between the natural chelates of the roots (organic acids) and the chitosan-iodine complexes, this is due to the high molecular weight of the Cs that may not be absorbed. A study in sunflower with iron chelated by humic acids of low and high molecular weight refers to this [28]. On the other hand, it has been shown that Cs and Cs nanoparticles can be in the cell walls of the subsidiary cells of the lower epidermis [29]. However, no reports were found that indicated the similar effect on roots.

The present study was undertaken with the hypothesis that it would be possible to increase the absorption of iodine applied to substrate if it was applied as an iodine-chitosan complex. The objective was to determine if potassium iodide or iodate complexed with chitosan led to more effective lettuce biofortification than either salt in their uncomplexed forms. 


\section{Materials and Methods}

\subsection{Preparation of Cs-KI, Cs-KIO 3 Complexes and Iodine Salts}

The Cs-KI and Cs- $\mathrm{KIO}_{3}$ complexes were prepared in the Center for Applied Chemistry Research (CIQA). The chitosan used had a viscometric molecular weight of $200,000 \mathrm{~g} / \mathrm{mol}$ and a $98 \%$ degree of deacetylation. First, a $1 \%$ Cs solution in $1 \%$ acetic acid $(\mathrm{AcOH})$ was prepared by adding the Cs little by little over $3 \mathrm{~h}$, with stirring at $300 \mathrm{rpm}$ until completely dissolved, at a temperature of $60-65^{\circ} \mathrm{C}$. The resulting solution was filtered and adjusted to $1 \mathrm{~L}$, for later use as the Cs controls.

For the iodine complexes, solutions of $0.1 \mathrm{~mol} \mathrm{dm}^{-3}$ potassium iodine (KI) and $0.1 \mathrm{~mol} \mathrm{dm}^{-3}$ potassium iodate $\left(\mathrm{KIO}_{3}\right)$ were dissolved in $1 \%$ Cs solution and adjusted to obtain complexes with Cs:I molar ratios of 5 . Thus, complexes with $1.06 \mathrm{mg}$ I per milliliter of complex solution were obtained.

For iodine salt-only treatments, solutions of $0.025 \mathrm{~mol} \mathrm{dm}^{-3} \mathrm{KI}$ and $0.025 \mathrm{~mol} \mathrm{dm}^{-3} \mathrm{KIO}_{3}$ were prepared in $1 \mathrm{~L}$ deionized water. Each solution contained $3.17 \mathrm{mg}$ I per milliliter.

\subsection{Vegetable Material and Applied Treatments}

The experimental work was performed in August 2017, in a greenhouse belonging to the Department of Horticulture, Agrarian Autonomous University Antonio Narro, in Saltillo, Mexico. Lettuce (Lactuca sativa), cv "Great Lakes," seeds were sown in 200-cell polystyrene trays filled with peat moss/perlite $(1: 1 \mathrm{v} / \mathrm{v})$ mix. When the seedlings reached a size of approximately $15 \mathrm{~cm}$, they were transplanted to $4 \mathrm{~L}$, black polyethylene pots filled with peat moss and perlite mix $(1: 1 \mathrm{v} / \mathrm{v})$. Before applying any treatments, a field capacity test was performed to evaluate the weight of the substrate. On average, a weight of $3 \mathrm{~kg}$ for substrate moistened to field capacity was obtained for each pot. The iodine concentrations used were 0,5 , and $25 \mathrm{mg} \mathrm{kg}^{-1}$ wet substrate, applied once, as well as $25 \mathrm{mg} \mathrm{I} \mathrm{kg}^{-1}$ wet substrate, applied as two doses of $12.5 \mathrm{mg} \mathrm{kg}^{-1}$ : before and 15 days after transplanting (d.a.t).

\subsubsection{Treatments Applied before Transplant}

For the treatments applied prior to transplanting, the total volume of substrate per pot was divided into three parts, while the iodine salt, $\mathrm{Cs}-\mathrm{KI}$, and $\mathrm{Cs}-\mathrm{KIO}_{3}$ treatments were split into two parts. The first part of each treatment was applied over the first third of substrate in the pot. Another third of substrate was added on top and the remaining half of the treatment was applied over the top. Afterwards, the remaining third of substrate was added to fill the pot. The lettuce seedlings were transplanted to those pots. We assume this procedure allows the plant roots to have $\mathrm{I}^{-}$and $\mathrm{IO}_{3}{ }^{-}$as salts or Cs complexes available as they grow.

Absolute controls (AC) only had water applied during the pot-filling process. Cs controls (CsC) had a total of $70.3 \mathrm{~mL} \mathrm{1 \%}$ Cs solution applied, to reach $0.2 \mathrm{~g}$ Cs per $\mathrm{kg}$ of substrate. Each treatment received the same final volume of $\mathrm{Cs}$.

For the $5 \mathrm{mg} \mathrm{I} \mathrm{kg}^{-1}$ substrate iodine salt treatments, a total of $4.7 \mathrm{~mL}$ of $0.025 \mathrm{~mol} \mathrm{dm}^{-3} \mathrm{KIO}_{3}$ and $0.025 \mathrm{~mol} \mathrm{dm}^{-3} \mathrm{KI}$, respectively, were added per pot. The $25 \mathrm{mg}$ I treatments required the addition of $23.6 \mathrm{~mL}$ of each respective solution per pot.

A total of $14.07 \mathrm{~mL}$ of $0.1 \mathrm{~mol} \mathrm{dm}{ }^{-3} \mathrm{Cs}-\mathrm{KI}$ and $0.1 \mathrm{~mol} \mathrm{dm}^{-3} \mathrm{Cs}-\mathrm{KIO}_{3}$ solutions were added to the respective pots for the $5 \mathrm{mg} \mathrm{I} \mathrm{kg}^{-1}$ treatments. To this, $56.2 \mathrm{~mL} \mathrm{1 \%} \mathrm{Cs} \mathrm{solution} \mathrm{per} \mathrm{pot} \mathrm{were} \mathrm{also}$ added in order to have the same Cs volume as in the controls. For the $25 \mathrm{mg}$ I treatments, $70.34 \mathrm{~mL}$ of $0.1 \mathrm{~mol} \mathrm{dm}^{-3} \mathrm{Cs}-\mathrm{KI}$ or $0.1 \mathrm{~mol} \mathrm{dm}^{-3} \mathrm{Cs}_{-} \mathrm{KIO}_{3}$ was added per pot.

\subsubsection{Treatments Applied before and after Transplant}

For each split dose application-SDA (12.5 and $\left.12.5 \mathrm{mg} \mathrm{kg}^{-1}\right)$ treatment, the same pot-filling procedure described above was used. All treatments received concentrations of $25 \mathrm{mg} \mathrm{I} \mathrm{kg}^{-1}$ substrate. The treatment volumes were divided in two, with each half applied while filling the pots by thirds. The last half of the treatment was applied after adding the second third of substrate, then the pot 
was filled by adding the last third of substrate. Afterwards, transplanting of the lettuce seedlings was performed as normal. The second application of the different treatments was applied by drench directly to the substrate at 15 d.a.t.

The experimental factors were arranged into a $2 \times 2 \times 4$ factorial array (iodine species $\times$ Cs polymer $\times$ concentration) and a totally randomized experimental design was utilized. The treatments thus evaluated were: (1) Control-Cs (CsC); (2) absolute control (AC); (3) $\mathrm{KIO}_{3} 5 \mathrm{mg} \mathrm{I} \mathrm{kg}^{-1}$ with Cs; (4) $\mathrm{KIO}_{3}$ $25 \mathrm{mg} \mathrm{I} \mathrm{kg}{ }^{-1}$ with Cs; (5) $\mathrm{KIO}_{3} 25 \mathrm{mg} \mathrm{I} \mathrm{kg}^{-1}$ with Cs, split-dose application; (6) $\mathrm{KIO}_{3} 5 \mathrm{mg} \mathrm{I} \mathrm{kg}^{-1}$ without $\mathrm{Cs}$; (7) $\mathrm{KIO}_{3} 25 \mathrm{mg} \mathrm{I} \mathrm{kg}^{-1}$ without Cs; (8) $\mathrm{KIO}_{3} 25 \mathrm{mg} \mathrm{I} \mathrm{kg}^{-1}$ without Cs, split-dose application; (9) $\mathrm{KI} 5 \mathrm{mg} \mathrm{I} \mathrm{kg}{ }^{-1}$ with Cs; (10) KI $25 \mathrm{mg} \mathrm{I} \mathrm{kg}^{-1}$ with Cs; (11) KI $25 \mathrm{mg} \mathrm{I} \mathrm{kg}^{-1}$ with Cs, split-dose application; (12) KI 5 mg I kg-1 without Cs; (13) KI $25 \mathrm{mg} \mathrm{I} \mathrm{kg}^{-1}$ without Cs; and, (14) KI $25 \mathrm{mg} \mathrm{I} \mathrm{kg}^{-1}$ without Cs, split-dose application. Two Cs controls and two absolute controls were also included, for 16 total treatments. The control groups were included in order to evaluate the potential effects that location within the greenhouse, where the rest of the treatments where distributed, might have. There were 12 experimental units per treatment, from which 6 plants were chosen at random for evaluation. A total of 96 plants were used for experimental evaluations.

An automated, single step drip irrigation system was used throughout the experiment. Steiner nutrient solution $(25 \%)$ was used for irrigation. A volume of $0.5 \mathrm{~L}$ solution was applied two times a day per pot. The solution $\mathrm{pH}$ was adjusted to 5.5-6.5 with phosphoric acid. Throughout the cultivation cycle, the electrical conductivity (EC) of the nutrient solution was maintained at approximately $1.40 \mathrm{mS} \mathrm{cm}{ }^{-1}$. Preventative treatment for whitefly was also applied. Within the greenhouse, the minimum temperature reached $8.3^{\circ} \mathrm{C}$, while the average was $17.7^{\circ} \mathrm{C}$, and the high was $32.4{ }^{\circ} \mathrm{C}$. The minimum relative humidity was $30.3 \%$, while the average and high were $54.8 \%$ and $75.5 \%$, respectively. The mean photosynthetically active radiation (PAR) was $432.3 \mu \mathrm{mol} \mathrm{m} \mathrm{m} \mathrm{s}^{-1}$ while the maximum was $864.7 \mu \mathrm{mol} \mathrm{m} \mathrm{m}^{-2} \mathrm{~s}^{-1}$, as measured with a WatchDog 1000 Series Micro Station, Spectrum technologies Inc., Aurora, IL, USA).

\subsection{Sampling}

The lettuces were harvested at 75 d.a.t. The 6 randomly chosen plants from each treatment were measured and weighed for their evaluation of biomass, mineral content, and iodine content (see Scheme 1). From those same plants, small samples from the central part of the heads were collected for the biochemical analyses. These lettuce head samples were kept in deep freeze and lyophilized.

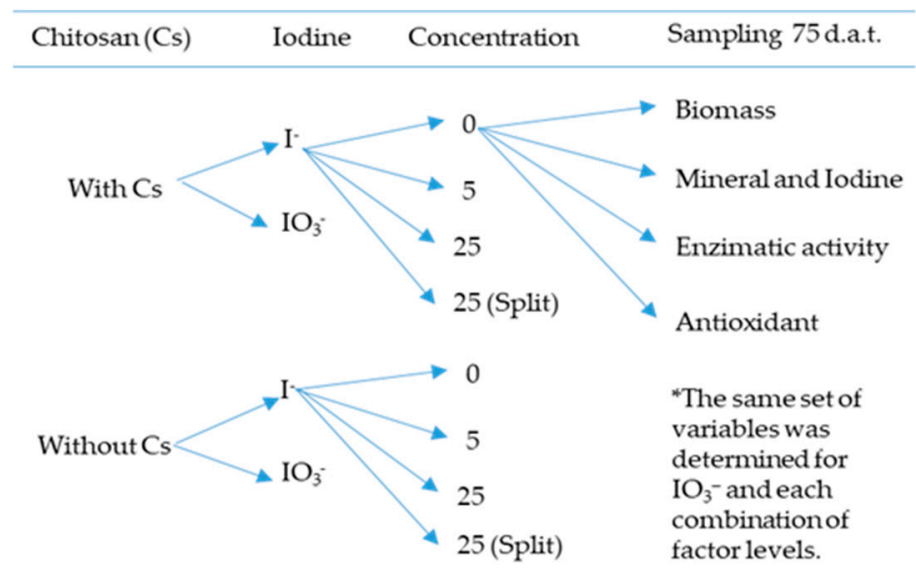

Scheme 1. Treatments and general variables evaluated.

\subsection{Biomass Production and Yields}

Lettuce heads and leaves were weighed on an precision balance (OHAUS). The values were recorded as the biomass fresh weight (FW). A small part from the central part of each head ( 10 g) was taken and stored at $-86^{\circ} \mathrm{C}$ for later determination of antioxidant and enzymatic activity. The heads' 
remaining fresh matter was placed in paper bags. The leaves were separated and also placed in paper bags. Both head stems and leaves were dried in dehydrating ovens for $72 \mathrm{~h}$ at $75 \pm 5^{\circ} \mathrm{C}$. Afterwards, their dry weights (DW) were recorded. Finally, mixed samples were prepared by combining the dry leaves and heads from each replica for each treatment. The mixed samples were placed in hermetic plastic bags for mineral analysis.

\subsection{Mineral Content}

\section{Determination}

Mineral content was determined from mixed samples of leaves and heads from 6 randomly chosen plants per treatment. Total nitrogen $(\mathrm{N})$ content was determined according to the Kjeldahl method [30]. A sample of dry matter $(0.05 \mathrm{~g})$ was weighed out and then acid digested in $4 \mathrm{~mL}$ of digest mix $(1 \mathrm{~L}$ of concentrated sulfuric acid with $25 \mathrm{~g}$ of potassium sulfate, $10 \mathrm{~g}$ of mercury red oxide, and $25 \mathrm{~mL}$ of saturated copper sulfate solution). The acid digest was then distilled along with $25 \mathrm{~mL} \mathrm{50 \%} \mathrm{sodium}$ hydroxide. From the resulting distillate, $30 \mathrm{~mL}$ were placed in a beaker containing $2.2 \%$ boric acid and 4 drops of bromocresol green and methyl red. The samples were titrated with $0.025 \mathrm{~N}$ sulfuric acid. $\mathrm{N}$ content was calculated from the volume of sulfuric acid consumed.

Phosphorus content was determined through spectrophotometry [30]. Readings were performed on a Genesys $10 \mathrm{~S}$ ultraviolet-visible (UV-Vis) spectrophotometer (Thermo Scientific, Waltham, MA, USA) at $640 \mathrm{~nm}$. The contents of $\mathrm{K}, \mathrm{Mg}, \mathrm{Ca}, \mathrm{Na}, \mathrm{Mn}, \mathrm{Zn}$, and Fe were determined by atomic absorption spectrometry following wet digestion [31]. One gram of dry matter was digested with nitric acid at $100^{\circ} \mathrm{C}$. Afterwards, the solution was filtered through Whatman, Buckinghamshire, United Kingdom (No. 42 ash-free) paper filters, diluted accordingly, and measured in a Varian AA-1275 flame atomic absorption spectroscope (Palo alto, CA, USA).

\subsection{Iodine Content Determination}

The alkaline ash technique [32,33] was used to determine iodine content. A sample of dried, ground leaves and heads $(0.5 \mathrm{~g})$ was weighed out. Six replicas per treatment were evaluated. The sample was placed in crucible of known, constant weight and $2 \mathrm{~mL} 2 \mathrm{~mol} \mathrm{dm}^{-3} \mathrm{KOH}$ and $1 \mathrm{~mL} 2 \mathrm{~mol} \mathrm{dm}^{-3} \mathrm{KNO}_{3}$ were added. After adding the reagents, pre-digestion took place while incubating in a stove at $100^{\circ} \mathrm{C}$ for $2 \mathrm{~h}$. The crucibles were placed in a muffle furnace at $580^{\circ} \mathrm{C}$ for $3 \mathrm{~h}$. After cooling back down to room temperature, the ashes were transferred to a conical tube for extraction with $2 \mathrm{~mL} 2 \mathrm{mM} \mathrm{KOH}$. The samples were centrifuged at 12,000 rpm for $15 \mathrm{~min}$. Finally, $1 \mathrm{~mL}$ of supernatant was decanted, and the volume adjusted to $10 \mathrm{~mL}$ with $2 \mathrm{~mol} \mathrm{dm}^{-3} \mathrm{KOH}$. Quantification was performed with an Agilent 725 ICP-OES (Inductively coupled plasma-optical emission spectrometry, Santa Clara, CA, USA).

\subsection{Chlorophyll Content Determination}

The contents of chlorophyll a (Chl a), chlorophyll b (Chl b), and total chlorophyll were determined according to the technique described in Munira et al. [34]. A sample (1 g) of fresh plant material was mixed with $5 \mathrm{~mL} \mathrm{90 \%} \mathrm{acetone.} \mathrm{A} \mathrm{pinch} \mathrm{of} \mathrm{magnesium} \mathrm{carbonate} \mathrm{was} \mathrm{added} \mathrm{to} \mathrm{protect} \mathrm{and} \mathrm{stabilize}$ the chlorophylls. From the homogenized mixtures, $2 \mathrm{~mL}$ were taken, placed in a $2 \mathrm{~mL}$ tube, and centrifuged for $5 \mathrm{~min}$. at 10,000 rpm and $4{ }^{\circ} \mathrm{C}$. The supernatants were decanted and the absorbances of $\mathrm{Chl}$ a and $\mathrm{Chl} b$ were read at $663 \mathrm{~nm}$ and $645 \mathrm{~nm}$, respectively. The total chlorophyll, $\mathrm{Chl} \mathrm{a}$, and Chl b content were expressed in $\mathrm{mg} \mathrm{g}^{-1}$, and were calculated according to the following formulas:

$$
\begin{gathered}
\text { Chlorophyll a }\left(\mathrm{mg} \cdot \mathrm{g}^{-1}\right)=25.38 \times \mathrm{A}_{663}+3.64 \times \mathrm{A}_{645} \\
\text { Chlorophyll b }\left(\mathrm{mg} \cdot \mathrm{g}^{-1}\right)=30.38 \times \mathrm{A}_{645}-6.58 \times \mathrm{A}_{663} \\
\text { Chlorophyll, total }\left(\mathrm{mg} \cdot \mathrm{g}^{-1}\right)=18.8 \times \mathrm{A}_{663}+34.02 \times \mathrm{A}_{645}
\end{gathered}
$$




\subsection{Biomolecule Extraction}

Lyophilized leaves ground into fine powder with a pestle and mortar were used for biomolecule extraction. From each treatment, $200 \mathrm{mg}$ samples of lyophilized leaves were placed in polypropylene microtubes. Polyvinylpyrrolidone $\left(20 \mathrm{mg}\right.$ ) and $1.5 \mathrm{~mL} 0.1 \mathrm{~mol} \mathrm{dm}^{-3}$ phosphate buffer ( $\left.\mathrm{pH} 7-7.2\right)$ were added, the samples were sonicated for $5 \mathrm{~min}$. and afterwards, centrifuged at 12,500 rpm for $10 \mathrm{~min}$. at $4{ }^{\circ} \mathrm{C}$. The supernatants were decanted and filtered through a nylon membrane. The filtrates were diluted 1:15 with phosphate buffer [35].

\subsection{Total Protein (TP) Content Determination}

The technique described by Bradford [36] was used for total protein content determination. From the biomolecule extracts, $100 \mu \mathrm{L}$ of extract were taken, placed in a test tube, and $1 \mathrm{~mL}$ of Bradford (Hercules, CA, USA) reagent was added. The samples with Bradford reagent were left to incubate for $5 \mathrm{~min}$. Afterwards, the absorbance was read at $595 \mathrm{~nm}$ in a Genesys $10 \mathrm{~S}$ UV-Vis spectrophotometer (Thermo Scientific). The results were recorded, and concentrations were extrapolated from a calibration curve prepared with bovine serum albumin (BSA). The protein concentrations were reported as $\mathrm{mg} \mathrm{g}^{-1}$.

\subsection{Free and Cell Wall-Bound Phenol Determination}

Phenolic compound content was determined according to the technique described by Gurr et al. [37]. Extraction was performed on 6 dried samples from each treatment. Methanol $(1 \mathrm{~mL})$ was added to each sample, the samples were vortexed, then centrifuged at $13,500 \mathrm{rpm}$ for $15 \mathrm{~min}$. The supernatants were decanted into vials and stored for the determination of free phenols. The remaining pellets were incubated with $0.25 \mathrm{~mL} 2 \mathrm{~mol} \mathrm{dm}{ }^{-3} \mathrm{NaOH}$ for $16 \mathrm{~h}$ at $70{ }^{\circ} \mathrm{C}$. Then, $0.25 \mathrm{~mL} 2 \mathrm{~N}$ hydrochloric acid was added, and the samples were centrifuged at 13,500 rpm for $15 \mathrm{~min}$. The resulting pellets were discarded, and the supernatants saved, as they were considered to contain the cell wall-bound phenols. To quantify the free and cell wall-bound phenols, $20 \mu \mathrm{L}$ of the corresponding supernatant were taken and mixed with $980 \mu \mathrm{L}$ distilled water, then $100 \mu \mathrm{L}$ Folin-Ciocalteau reagent was added, and the mixture left to incubate for $5 \mathrm{~min}$. Subsequently, $600 \mu \mathrm{L}$ of sodium bicarbonate solution saturated with $0.1 \mathrm{~mol} \mathrm{dm}^{-3} \mathrm{NaOH}$ were added. The samples were left to incubate for $2.5 \mathrm{~h}$. The sample absorbance was read at $725 \mathrm{~nm}$ and the results were expressed as $\mathrm{mg}$ of gallic acid equivalents per $\mathrm{g}^{-1}$ dry weight (DW).

\subsection{Superoxide Dismutase (SOD) Determination}

The biomolecule extract was assayed for superoxide dismutase (SOD) activity using the CAYMAN@SOD, assay kit (Ann Arbor, MI, USA). SOD activity can be quantified spectrophotometrically by measuring the oxidation of WST (water soluble tetrazolium salt) to WST-formazan by superoxide ions created by xanthine $(X) /$ xanthine oxidase complexes. The inhibition of WST oxidation is attributed to the neutralization of superoxide radicals by SOD. The units of SOD activity were expressed in $\mathrm{U} / \mathrm{mL}$. The microwell assay plates were read at $450 \mathrm{~nm}$ in an Elx808 plate reader (BioTek, Winooski, VT, USA).

\subsection{Catalase Activity Determination}

Catalase activity was quantified by spectrophotometry. Two reaction times, T0 and T1, were recorded for this technique. The blank solution was prepared by mixing $0.1 \mathrm{~mL}$ biomolecule extract, $1 \mathrm{~mL}$ phosphate buffer ( $\mathrm{pH} 7.2)$, and $0.4 \mathrm{~mL}$ of $5 \% \mathrm{H}_{2} \mathrm{SO}_{4}$. For measuring the reactions at $\mathrm{T} 0$, $0.1 \mathrm{~mL}$ of biomolecule extract was mixed with $1 \mathrm{~mL} 100 \mathrm{mM} \mathrm{H}_{2} \mathrm{O}_{2}$ and immediately after, $0.5 \mathrm{~mL}$ $5 \% \mathrm{H}_{2} \mathrm{SO}_{4}$. For the $\mathrm{T} 1$ samples, the same mix was prepared except that the $0.5 \mathrm{~mL} 5 \% \mathrm{H}_{2} \mathrm{SO}_{4}$ was added after $1 \mathrm{~min}$. The reaction between extract and peroxide occurred at $20{ }^{\circ} \mathrm{C}$ with constant agitation. Finally, the consumption of $\mathrm{H}_{2} \mathrm{O}_{2}$ was determined by reading the absorbance at $270 \mathrm{~nm}$ in a 
UV-Vis spectrophotometer. The catalase activity units were expressed in $\mathrm{mM}_{2} \mathrm{O}_{2}$ per total protein content [38].

\subsection{Glutathione Peroxidase (GPX) Quantification}

Quantification of glutathione peroxidase was performed using the method described by Xue et al. [39], using $\mathrm{H}_{2} \mathrm{O}_{2}$ as a substrate. Biomolecule extract $(0.2 \mathrm{~mL}), 0.1 \mathrm{~mol} \mathrm{dm}^{-3}$ reduced glutathione $(0.4 \mathrm{~mL})$, and $0.067 \mathrm{~mol} \mathrm{dm}^{-3} \mathrm{Na}_{2} \mathrm{HPO}_{4}(0.2 \mathrm{~mL})$ were placed in a test tube. The mixture was heated in a $25{ }^{\circ} \mathrm{C}$ water bath for $5 \mathrm{~min}$., then $1.3 \mathrm{mM} \mathrm{H}_{2} \mathrm{O}_{2}(0.2 \mathrm{~mL})$ was added to start the catalytic reaction. The mixture was allowed to react for $10 \mathrm{~min}$. and then was stopped with the addition of $1 \mathrm{~mL} 1 \%$ trichloroacetic acid. The mixture was left in an ice bath for $30 \mathrm{~min}$. Afterwards, it was centrifuged at $3000 \mathrm{rpm}$ for $10 \mathrm{~min}$. A sample of supernatant $(0.48 \mathrm{~mL})$ was placed in a test tube, along

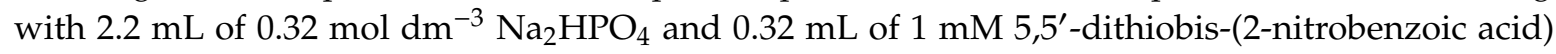
(DTNB). The absorbance of the reaction mixture was read at $412 \mathrm{~nm}$ in a UV-Vis spectrophotometer. The catalytic activity of glutathione peroxidase was expressed as $\mathrm{mM}$ glutathione per minute per total protein content.

\subsection{Glutathione (GSH) Quantification}

Glutathione (GSH) content was quantified according to the spectrophotometric technique established by Xue et al. [39], utilizing the reaction with 5,5'-DTNB. Biomolecule extract $(0.48 \mathrm{~mL})$, $0.067 \mathrm{~mol} \mathrm{dm}^{-3} \mathrm{Na}_{2} \mathrm{HPO}_{4}(2.2 \mathrm{~mL})$, and $1 \mathrm{mM}$ DTNB dye $(0.32 \mathrm{~mL})$ were placed in a test tube and mixed. The absorbance of the samples was read at $412 \mathrm{~nm}$ in a UV-Vis spectrophotometer. Values were reported as $\mathrm{mg} \mathrm{L}^{-1}$.

\subsection{Antioxidant Capacity Determination by ABTS ${ }^{\bullet+}$}

Total antioxidant content was determined using the CAYMAN@Antioxidant assay kit. The assay determines antioxidant content based on a sample's ability to inhibit the oxidation of ABTS ${ }^{\bullet+}$ (2,2'-azino-di-[3-ethylbenzthiazoline sulphonate]). The quantity of ABTS radicals produced was determined by reading the microwell plate at $405 \mathrm{~nm}$. The reported values were expressed in $\mathrm{mM}$.

\subsection{Statistical Analyses}

A completely randomized experimental design was used, with 6 repetitions per treatment. A single pot with one plant was considered an experimental unit. The collected data was subjected to analysis of variance (ANOVA) and to separation of means using Fisher's least significant difference (LSD, $p=0.05$ ) tests, using the 2018 InfoStat statistical analysis software package (InfoStat Group, Córdoba, Argentina).

\section{Results}

\subsection{Biomass Production and Yields}

According to the ANOVA presented in Table 1, the concentration of iodine (C) only had no impact on the leaf dry weight (LDW) of lettuce. On average, there were positive effects on biomass at iodine concentrations of $5 \mathrm{mg} \mathrm{kg}^{-1}$ observed. No interactions between $C$ and the presence of $C$ s or the different iodine species were observed. Also, there were no treatments that affected all the biomass variables evaluated. For example, some treatments, such as $\mathrm{Cs}_{-}-\mathrm{KIO}_{3}\left(5 \mathrm{mg} \mathrm{kg}{ }^{-1}\right)$, significantly increased leaf dry weight (LDW) while others (doubly applied Cs-KI, $25 \mathrm{mg} \mathrm{kg}^{-1}$ ) significantly decreased the lettuce head fresh weight (HFW). It was only for the leaf fresh weight (LFW) that an interaction between iodine and Cs could be observed, as that value increased following application of $\mathrm{Cs}-\mathrm{KIO}_{3}\left(5 \mathrm{mg} \mathrm{kg}{ }^{-1}\right)$. The two factors together appeared to play an important role in biomass increase. However, in general, for the evaluated biomass parameters, the source of iodine was an important determining factor, since there were significant differences associated with this variable, except for the head dry weight parameter. 
Table 1. Comparison of lettuce biomass means.

\begin{tabular}{|c|c|c|c|c|c|}
\hline \multirow{2}{*}{ Treatments } & \multirow{2}{*}{ Concentration (mg I kg-1 Substrate) } & \multicolumn{4}{|c|}{ g plant $^{-1}(n=6)$} \\
\hline & & LFW & HFW & LDW & HDW \\
\hline $\mathrm{CsC}$ & 0 & $212.00 \mathrm{~b}-\mathrm{d}$ & $667.63 \mathrm{ab}$ & $17.62 \mathrm{c}-\mathrm{e}$ & $28.48 \mathrm{a}-\mathrm{d}$ \\
\hline $\mathrm{Cs}-\mathrm{KIO}_{3}$ & 5 & $294.32 \mathrm{a}$ & $695.52 \mathrm{a}$ & $24.27 \mathrm{a}$ & $34.05 \mathrm{a}$ \\
\hline $\mathrm{Cs}-\mathrm{KIO}_{3}$ & 25 & $264.95 \mathrm{ab}$ & $634.78 \mathrm{ab}$ & $22.50 \mathrm{ab}$ & $33.80 \mathrm{a}$ \\
\hline $\mathrm{Cs}-\mathrm{KIO}_{3} \mathrm{SDA}$ & 25 & $235.85 \mathrm{a}-\mathrm{c}$ & $582.67 \mathrm{ab}$ & $19.58 \mathrm{a}-\mathrm{c}$ & $29.28 \mathrm{a}-\mathrm{c}$ \\
\hline $\mathrm{AC}$ & 0 & $146.72 \mathrm{e}-\mathrm{f}$ & $534.50 \mathrm{ab}$ & 14.63 de & $22.37 \mathrm{~d}-\mathrm{e}$ \\
\hline $\mathrm{KIO}_{3}$ & 5 & $201.42 \mathrm{c}-\mathrm{f}$ & $579.57 \mathrm{ab}$ & $18.50 \mathrm{~b}-\mathrm{d}$ & 19.13 ef \\
\hline $\mathrm{KIO}_{3}$ & 25 & $201.17 \mathrm{c}-\mathrm{f}$ & $595.68 \mathrm{ab}$ & $16.97 c-e$ & $24.65 \mathrm{~b}-\mathrm{e}$ \\
\hline $\mathrm{KIO}_{3} \mathrm{SDA}$ & 25 & $178.15 \mathrm{c}-\mathrm{f}$ & $499.05 \mathrm{~b}$ & $16.65 c-e$ & $19.95 \mathrm{ef}$ \\
\hline $\mathrm{CsC}$ & 0 & $196.97 \mathrm{c}-\mathrm{f}$ & $596.07 \mathrm{ab}$ & $17.57 \mathrm{c}-\mathrm{e}$ & $24.20 \mathrm{~b}-\mathrm{e}$ \\
\hline Cs-KI & 5 & $190.12 \mathrm{c}-\mathrm{f}$ & $577.57 \mathrm{ab}$ & $16.47 \mathrm{c}-\mathrm{e}$ & $24.92 \mathrm{~b}-\mathrm{e}$ \\
\hline Cs-KI & 25 & $155.77 \mathrm{~d}-\mathrm{f}$ & $526.18 \mathrm{ab}$ & $13.67 \mathrm{e}$ & $22.70 \mathrm{c}-\mathrm{e}$ \\
\hline Cs-KI SDA & 25 & $143.04 \mathrm{f}$ & $280.17 \mathrm{c}$ & 14.73 de & $15.03 \mathrm{f}$ \\
\hline $\mathrm{AC}$ & 0 & $194.55 \mathrm{c}-\mathrm{f}$ & $499.48 \mathrm{~b}$ & $17.37 \mathrm{c}-\mathrm{e}$ & $25.87 \mathrm{~b}-\mathrm{e}$ \\
\hline KI & 5 & $214.85 \mathrm{~b}-\mathrm{d}$ & $587.67 \mathrm{ab}$ & $19.13 b-d$ & $29.57 \mathrm{ab}$ \\
\hline KI & 25 & $205.10 \mathrm{~b}-\mathrm{e}$ & $581.43 \mathrm{ab}$ & $18.90 \mathrm{~b}-\mathrm{d}$ & $27.48 \mathrm{a}-\mathrm{d}$ \\
\hline KI SDA & 25 & $177.78 \mathrm{c}-\mathrm{f}$ & $495.32 \mathrm{~b}$ & $17.43 \mathrm{c}-\mathrm{e}$ & $24.95 \mathrm{~b}-\mathrm{e}$ \\
\hline Concentration $(\mathrm{C})$ & & 0.0311 & 0.0077 & ns & 0.0198 \\
\hline Chitosan (Cs) & & 0.0494 & ns & ns & ns \\
\hline Chemical species (CSp) & & 0.0041 & 0.0116 & 0.0229 & ns \\
\hline $\mathrm{C} \times \mathrm{Cs}$ & & ns & $\mathrm{ns}$ & $\mathrm{ns}$ & ns \\
\hline $\mathrm{C} \times \mathrm{CSp}$ & & ns & ns & ns & ns \\
\hline $\mathrm{Cs} \times \mathrm{CSp}$ & & $<0.0001$ & ns & 0.0001 & $<0.0001$ \\
\hline $\mathrm{C} \times \mathrm{Cs} \times \mathrm{CSp}$ & & ns & ns & ns & ns \\
\hline
\end{tabular}

Means with the same letter are statistically identical (least significant difference (LSD), $p \leq 0.05$ ); sample size, 6 $(n=6)$, ns, not significant. SDA, split dose application; LFW, leaf fresh weight; HFW, head fresh weight; LDW, leaf dry weight; HDW, head dry weight.

\subsection{Mineral Content}

\subsubsection{Macronutrient Content}

Neither iodine source, be it $\mathrm{I}^{-}$or $\mathrm{IO}_{3}{ }^{-}$, generally appeared to have antagonistic effects on the macroelements evaluated. The iodine species used, their concentrations, and the presence of Cs polymer had effects on various elements, when compared to other treatments, although there were hardly any differences between treatments and their respective controls with and without Cs (Table 2). Only magnesium concentrations increased significantly after application of $5 \mathrm{mg} \mathrm{I} \mathrm{kg}^{-1} \mathrm{Cs}-\mathrm{KI}$. There were significant differences among the Cs controls, although this was probably due to their location within the greenhouse. This is why the increases in Ca and Na after application of Cs-KI ( $\left.5 \mathrm{mg} \mathrm{kg}^{-1}\right)$ cannot be considered significant, because even though their closest, neighboring Cs controls had lower contents of those elements, comparison with the other chitosan controls showed no differences. The interaction between the effects of concentration and iodine species were statistically significant for the concentrations of almost all the elements evaluated, except for K. On average, application of $\mathrm{IO}_{3}{ }^{-}$salts led to greater accumulation of macroelements than their $\mathrm{I}^{-}$counterparts. However, these differences were not significant with respect to the controls.

\subsubsection{Micronutrient Content}

The source of iodine $\left(\mathrm{I}^{-}\right.$or $\left.\mathrm{IO}_{3}{ }^{-}\right)$had a significant effect on the concentrations of microelements in lettuce. As observed with the macroelements, there were no antagonistic effects between the application of iodine and the concentrations of microelements (Table 3). Apart from that, there was a significant increase in Mn when Cs-KI is applied (single application, $25 \mathrm{mg} \mathrm{I} \mathrm{kg}^{-1}$ ). On the other hand, it appears that the interaction between iodine concentrations and Cs did not exert any significant effects on microelement concentrations. 
Table 2. Macroelement contents in mixed samples of lettuce leaves and heads.

\begin{tabular}{|c|c|c|c|c|c|c|c|}
\hline \multirow{2}{*}{ Treatments } & \multirow{2}{*}{ Concentration (mg I kg ${ }^{-1}$ Substrate) } & \multicolumn{6}{|c|}{$\%$ Dry Weight $(n=6)$} \\
\hline & & $\mathbf{N}$ & $\mathbf{P}$ & $\mathbf{K}$ & $\mathrm{Ca}$ & $\mathrm{Mg}$ & $\mathrm{Na}$ \\
\hline $\mathrm{CsC}$ & 0 & $0.82 \mathrm{~b}$ & $0.43 \mathrm{a}$ & $13.27 \mathrm{a}$ & $4.20 \mathrm{ab}$ & $5.78 \mathrm{~b}$ & $13.97 \mathrm{a}$ \\
\hline $\mathrm{Cs}-\mathrm{KIO}_{3}$ & 5 & $1.29 \mathrm{ab}$ & $0.40 \mathrm{a}$ & $12.01 \mathrm{ab}$ & $2.25 \mathrm{~cd}$ & $3.91 \mathrm{c}$ & $7.57 \mathrm{~b}$ \\
\hline $\mathrm{Cs}-\mathrm{KIO}_{3}$ & 25 & $1.48 \mathrm{a}$ & $0.24 \mathrm{~b}-\mathrm{e}$ & $10.81 \mathrm{a}-\mathrm{c}$ & $2.08 \mathrm{c}-\mathrm{e}$ & $3.62 \mathrm{~cd}$ & $3.91 \mathrm{bc}$ \\
\hline $\mathrm{Cs}-\mathrm{KIO}_{3} \mathrm{SDA}$ & 25 & $1.40 \mathrm{ab}$ & $0.25 \mathrm{~b}-\mathrm{d}$ & $8.06 \mathrm{~b}-\mathrm{d}$ & $1.00 \mathrm{~d}-\mathrm{f}$ & $2.20 \mathrm{de}$ & $3.24 \mathrm{c}$ \\
\hline $\mathrm{AC}$ & 0 & $1.33 \mathrm{ab}$ & $0.26 \mathrm{~b}-\mathrm{d}$ & $8.15 b-d$ & $1.71 \mathrm{c}-\mathrm{f}$ & $1.91 \mathrm{e}$ & $3.16 \mathrm{c}$ \\
\hline $\mathrm{KIO}_{3}$ & 5 & $1.21 \mathrm{ab}$ & $0.20 c-g$ & $7.73 \mathrm{~b}-\mathrm{d}$ & $1.87 \mathrm{c}-\mathrm{f}$ & $2.25 c-e$ & $3.41 \mathrm{c}$ \\
\hline $\mathrm{KIO}_{3}$ & 25 & $1.55 \mathrm{a}$ & $0.22 \mathrm{~b}-\mathrm{f}$ & $8.06 \mathrm{~b}-\mathrm{d}$ & $2.95 \mathrm{bc}$ & $3.08 \mathrm{c}-\mathrm{e}$ & $6.03 \mathrm{bc}$ \\
\hline $\mathrm{KIO}_{3} \mathrm{SDA}$ & 25 & $1.36 \mathrm{ab}$ & $0.29 \mathrm{~b}$ & $6.61 \mathrm{~cd}$ & $1.50 \mathrm{~d}-\mathrm{f}$ & $2.70 c-e$ & $4.32 \mathrm{bc}$ \\
\hline $\mathrm{CsC}$ & 0 & $1.21 \mathrm{ab}$ & $0.20 \mathrm{c}-\mathrm{g}$ & $6.78 \mathrm{~cd}$ & $1.41 \mathrm{~d}-\mathrm{f}$ & $2.33 c-e$ & $3.78 \mathrm{bc}$ \\
\hline Cs-KI & 5 & $1.43 \mathrm{ab}$ & $0.28 \mathrm{bc}$ & $7.48 \mathrm{~b}-\mathrm{d}$ & $5.24 \mathrm{a}$ & $7.90 \mathrm{a}$ & $14.26 \mathrm{a}$ \\
\hline Cs-KI & 25 & $1.19 \mathrm{ab}$ & $0.24 \mathrm{~b}-\mathrm{d}$ & $6.91 \mathrm{~cd}$ & $1.29 \mathrm{~d}-\mathrm{f}$ & $2.33 c-e$ & $3.25 c$ \\
\hline Cs-KI SDA & 25 & $1.01 \mathrm{ab}$ & $0.12 \mathrm{~g}$ & $5.49 \mathrm{~d}$ & $1.21 \mathrm{~d}-\mathrm{f}$ & $2.20 \mathrm{de}$ & $3.29 c$ \\
\hline $\mathrm{AC}$ & 0 & $1.13 \mathrm{ab}$ & $0.15 \mathrm{e}-\mathrm{g}$ & $5.53 \mathrm{~d}$ & 0.75 ef & 2.04 de & $2.62 \mathrm{c}$ \\
\hline KI & 5 & $1.18 \mathrm{ab}$ & $0.13 \mathrm{~g}$ & $8.02 \mathrm{~b}-\mathrm{d}$ & $0.96 \mathrm{~d}-\mathrm{f}$ & $2.37 \mathrm{c}-\mathrm{e}$ & $5.41 \mathrm{bc}$ \\
\hline KI & 25 & $0.93 \mathrm{ab}$ & $0.14 \mathrm{fg}$ & $6.15 \mathrm{~cd}$ & $1.08 \mathrm{~d}-\mathrm{f}$ & $1.91 \mathrm{e}$ & $2.95 \mathrm{c}$ \\
\hline KI SDA & 25 & $1.07 \mathrm{ab}$ & $0.19 \mathrm{~d}-\mathrm{g}$ & $4.16 \mathrm{~d}$ & $0.67 \mathrm{f}$ & $1.54 \mathrm{e}$ & $2.53 c$ \\
\hline Concentration $(\mathrm{C})$ & & ns & 0.0001 & 0.0004 & $<0.0001$ & $<0.0001$ & ns \\
\hline Chitosan (Cs) & & ns & $<0.0001$ & $<0.0001$ & $<0.0001$ & $<0.0001$ & 0.0107 \\
\hline Chemical Species (CSp) & & 0.0147 & $<0.0001$ & $<0.0001$ & $<0.0001$ & 0.0368 & ns \\
\hline $\mathrm{C} \times \mathrm{Cs}$ & & ns & $<0.0001$ & ns & $<0.0001$ & $<0.0001$ & ns \\
\hline $\mathrm{C} \times \mathrm{CSp}$ & & 0.006 & $<0.0001$ & ns & $<0.0001$ & $<0.0001$ & 0.0061 \\
\hline $\mathrm{Cs} \times \mathrm{CSp}$ & & ns & ns & 0.0049 & 0.0002 & ns & ns \\
\hline $\mathrm{C} \times \mathrm{Cs} \times \mathrm{CSp}$ & & ns & 0.0006 & ns & $<0.0001$ & $<0.0001$ & ns \\
\hline
\end{tabular}

Means with the same letter are statistically identical (LSD, $p \leq 0.05)$; sample size, $6(\mathrm{n}=6)$, ns, not significant.

Table 3. Microelement content in mixed samples of lettuce leaves and heads.

\begin{tabular}{|c|c|c|c|c|c|}
\hline \multirow{2}{*}{ Treatments } & \multirow{2}{*}{ Concentration (mg I kg-1 Substrate) } & \multicolumn{4}{|c|}{$\mathrm{mg} \mathrm{kg}^{-1}$ Dry Weight $(\mathrm{n}=6)$} \\
\hline & & Zn & $\mathrm{Fe}$ & Mn & $\mathrm{Cu}$ \\
\hline $\mathrm{CsC}$ & 0 & $49.24 \mathrm{a}$ & $166.17 \mathrm{a}-\mathrm{c}$ & 86.49 de & $3.82 \mathrm{ab}$ \\
\hline $\mathrm{Cs}-\mathrm{KIO}_{3}$ & 5 & $45.89 \mathrm{ab}$ & $156.47 \mathrm{a}-\mathrm{d}$ & $79.15 \mathrm{e}$ & $4.16 \mathrm{a}$ \\
\hline $\mathrm{Cs}-\mathrm{KIO}_{3}$ & 25 & $37.77 \mathrm{~b}$ & $157.72 \mathrm{a}-\mathrm{d}$ & 88.35 de & $3.83 \mathrm{ab}$ \\
\hline $\mathrm{Cs}-\mathrm{KIO}_{3} \mathrm{SDA}$ & 25 & $40.05 \mathrm{ab}$ & $158.38 \mathrm{a}-\mathrm{d}$ & $90.40 \mathrm{c}-\mathrm{e}$ & $3.99 \mathrm{a}$ \\
\hline $\mathrm{AC}$ & 0 & $39.24 \mathrm{ab}$ & $171.09 \mathrm{ab}$ & $97.76 \mathrm{~b}-\mathrm{e}$ & $2.99 \mathrm{ab}$ \\
\hline $\mathrm{KIO}_{3}$ & 5 & $41.25 \mathrm{ab}$ & $181.96 \mathrm{a}$ & $96.31 \mathrm{~b}-\mathrm{e}$ & $2.99 \mathrm{ab}$ \\
\hline $\mathrm{KIO}_{3}$ & 25 & $42.56 \mathrm{ab}$ & $132.33 \mathrm{~b}-\mathrm{e}$ & $106.89 \mathrm{~b}-\mathrm{e}$ & $3.49 \mathrm{ab}$ \\
\hline $\mathrm{KIO}_{3} \mathrm{SDA}$ & 25 & $42.72 \mathrm{ab}$ & 143.96 a-e & $125.02 \mathrm{a}-\mathrm{c}$ & $3.66 \mathrm{ab}$ \\
\hline $\mathrm{CsC}$ & 0 & $39.56 \mathrm{ab}$ & $133.65 \mathrm{~b}-\mathrm{d}$ & $98.74 \mathrm{~b}-\mathrm{e}$ & $2.83 \mathrm{ab}$ \\
\hline Cs-KI & 5 & $39.91 \mathrm{ab}$ & $133.55 \mathrm{~b}-\mathrm{e}$ & $131.72 \mathrm{ab}$ & $3.66 \mathrm{ab}$ \\
\hline Cs-KI & 25 & $41.75 \mathrm{ab}$ & $137.41 \mathrm{~b}-\mathrm{e}$ & $150.55 \mathrm{a}$ & $3.16 \mathrm{ab}$ \\
\hline Cs-KI SDA & 25 & $41.89 \mathrm{ab}$ & $138.14 \mathrm{~b}-\mathrm{e}$ & $116.86 \mathrm{a}-\mathrm{d}$ & $3.49 \mathrm{ab}$ \\
\hline $\mathrm{AC}$ & 0 & $36.09 \mathrm{~b}$ & 120.26 de & $85.00 \mathrm{de}$ & $3.00 \mathrm{ab}$ \\
\hline KI & 5 & $37.59 \mathrm{~b}$ & $100.78 \mathrm{e}$ & $107.77 \mathrm{~b}-\mathrm{e}$ & $2.99 \mathrm{ab}$ \\
\hline KI & 25 & $37.91 \mathrm{ab}$ & $125.86 \mathrm{c}-\mathrm{e}$ & $120.70 \mathrm{a}-\mathrm{d}$ & $3.33 \mathrm{ab}$ \\
\hline KI SDA & 25 & $36.56 \mathrm{~b}$ & $129.45 \mathrm{~b}-\mathrm{e}$ & $108.19 \mathrm{~b}-\mathrm{e}$ & $2.49 \mathrm{~b}$ \\
\hline Concentration $(\mathrm{C})$ & & ns & ns & 0.0001 & ns \\
\hline Chitosan (Cs) & & 0.0177 & 0.0333 & ns & 0.0012 \\
\hline Chemical Species (CSp) & & 0.0036 & $<0.0001$ & $<0.0001$ & 0.0013 \\
\hline $\mathrm{C} \times \mathrm{Cs}$ & & ns & ns & ns & ns \\
\hline $\mathrm{C} \times \mathrm{CSp}$ & & ns & 0.0051 & 0.0003 & ns \\
\hline $\mathrm{Cs} \times \mathrm{CSp}$ & & ns & ns & $<0.0001$ & ns \\
\hline $\mathrm{C} \times \mathrm{Cs} \times \mathrm{CSp}$ & & 0.0492 & 0.0211 & ns & ns \\
\hline
\end{tabular}

Means with the same letter are statistically identical (LSD, $p \leq 0.05)$; sample size, $6(\mathrm{n}=6)$, ns, not significant.

\subsubsection{Iodine and Minerals Correlation Analysis}

A general analysis of correlation between iodine and each mineral element was carried out (Table 4). Of the elements evaluated, manganese, potassium, and calcium demonstrated significant correlations. Manganese had a positive correlation while for the other two, the correlation was negative. Regardless, the correlation values of each element with iodine are low. In that case, biofortification with iodine is not expected to interfere with the assimilation or accumulation of other mineral elements. There are various scales used to score Spearman correlation coefficients [40]. For this research, scale 2 was chosen. That scale indicates that a Spearman coefficient greater than $|0.5|$ corresponds to a moderately strong correlation. 
Table 4. Correlation analysis of iodine and minerals.

\begin{tabular}{ccccc}
\hline Treatments & Variable 1 & Variable 2 & Spearman & $p$-value \\
\hline & & Zinc & -0.04 & 0.7056 \\
& Manganese & 0.4 & 0.0001 \\
& Iron & -0.06 & 0.5316 \\
General treatment & Copper & -0.03 & 0.7894 \\
analysis & & Sodium & -0.16 & 0.1275 \\
& & Potassium & -0.31 & 0.0018 \\
& & Nitrogen & 0.05 & 0.6013 \\
& & Magnesium & -0.18 & 0.0827 \\
& & Phosphorus & -0.17 & 0.0951 \\
& & Calcium & -0.22 & 0.0301 \\
\hline
\end{tabular}

Values of $\alpha \leq 0.05$ are significant. Spearman correlation coefficients greater than +0.5 indicate positive, moderately strong correlations or less than -0.5 indicate negative, moderately strong correlations, according to a previously described scale [40].

\subsection{Iodine Content in Lettuce}

The highest concentrations of iodine were seen in lettuce subjected to the SDA treatments (25 mg I kg${ }^{-1} \mathrm{KI}$ or $\mathrm{KIO}_{3}$ ), regardless of Cs (Figure 1). SDA of KI and Cs-KI increased lettuce iodine concentrations to levels 77.9- and 63.7-times, respectively, above the corresponding controls. Similarly, SDA of $\mathrm{KIO}_{3}$ and $\mathrm{Cs}-\mathrm{KIO}_{3}$ increased concentrations by factors of 97.4 and 36.4, respectively. The highest recorded concentration was $103.16 \mathrm{mg} \mathrm{I} \mathrm{kg}^{-1}$ dry weight (DW), following SDA of $\mathrm{KIO}_{3}$ $\left(25 \mathrm{mg} \mathrm{I} \mathrm{kg}^{-1}\right)$. Apart from those results, single applications of $\mathrm{Cs}^{-} \mathrm{KIO}_{3}$ and $\mathrm{KIO}_{3}\left(25 \mathrm{mg} \mathrm{I} \mathrm{kg}^{-1}\right)$ also led to improvements in iodine concentrations (17.4- and 18.2-times above control concentrations, respectively). Single applications of KI and Cs-KI $\left(25 \mathrm{mg} \mathrm{I} \mathrm{kg}^{-1}\right)$ increased iodine concentrations by factors of 14.4 and 24.4, respectively. However, these improvements were not significant. According to the analysis of variance the iodine species did not have a significant impact on the results, rather the concentrations applied, and the presence of chitosan were the statistically important factors. The only interaction with significant differences that the iodine species factor had was with the chitosan factor (Figure 1).

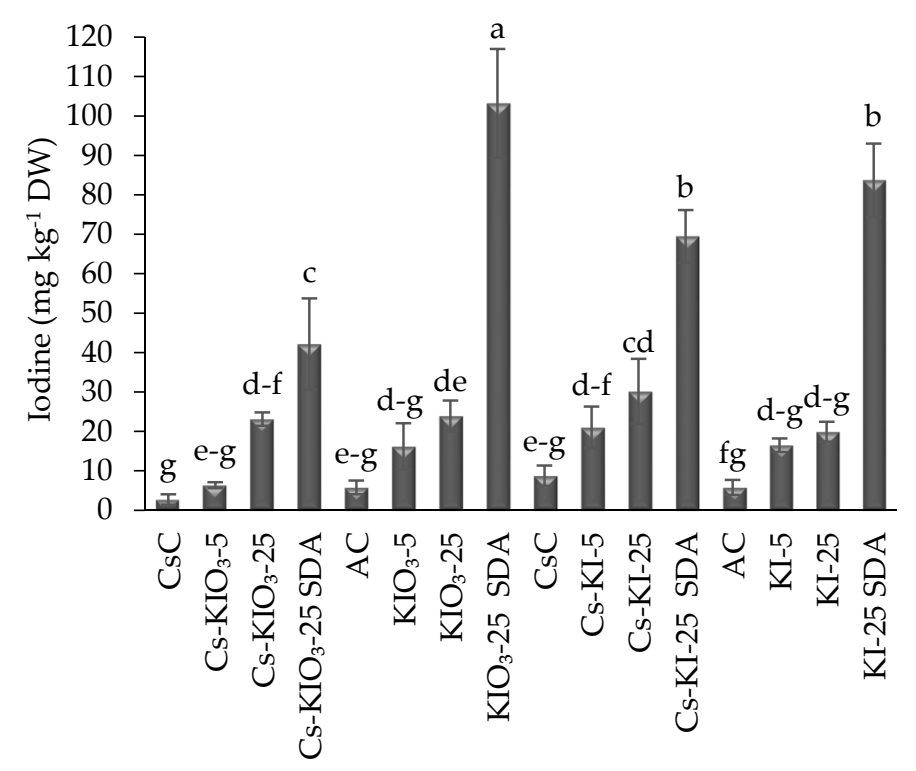

Figure 1. Iodine concentrations in mixed samples of lettuce leaves and heads following iodine salt treatments with and without chitosan. Means with the same letter are statistically identical (LSD, $p \leq 0.05)$; the bars represent the standard error $(n=6)$. 


\subsection{Cell Wall-Bound and Free Phenol Content}

Only $\mathrm{KIO}_{3}$ at high concentrations ( $\left.25 \mathrm{mg} \mathrm{I} \mathrm{kg}^{-1}\right)$, both singly and doubly applied, led to increases in wall-bound phenols compared to the absolute controls (Figure 2). None of the factors alone had significant effects on phenol concentrations. However, the interaction between the iodine species and chitosan factors led to significant differences between treatments, as did the interaction between all three experimental factors. Conversely, there was neither a positive nor negative effect on the concentration of free phenols. Overall, the presence or absence of Cs, along with either iodine salt, had little to no effect on phenol content.
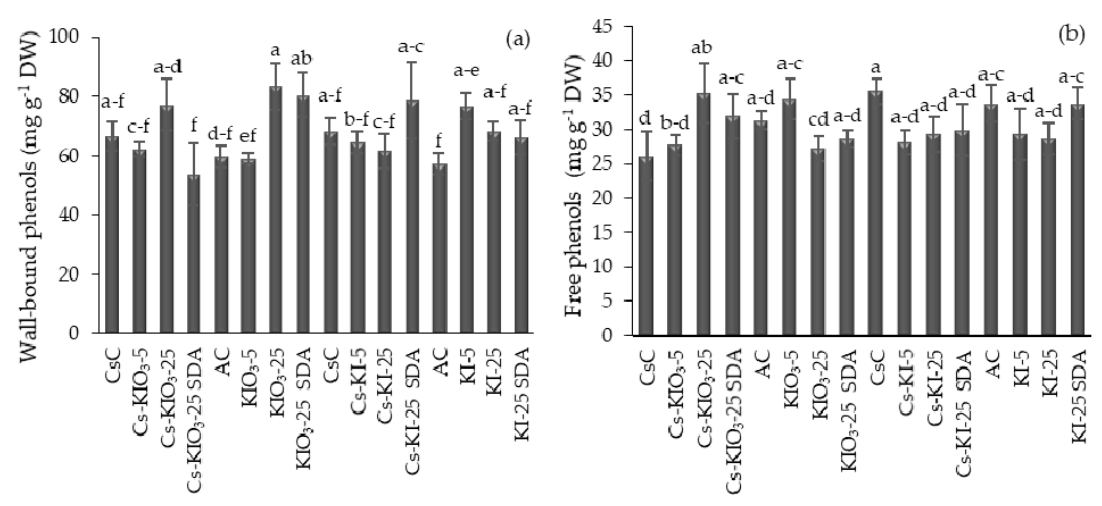

Figure 2. (a) Content of cell wall-bound phenols. (b) Content of free phenols measured in dry lettuce samples. Means with the same letter are statistically identical (LSD, $p \leq 0.05$ ); the bars represent the standard error $(\mathrm{n}=6)$.

\subsection{Chlorophyll Content}

According to the analysis of variance, only the interaction between chitosan and the different iodine species had an effect on $\mathrm{Chl}$ a and total chlorophyll $(\mathrm{Ct})$. However, with respect to the controls, there were no significant differences (Table 5). The $\mathrm{Chl} \mathrm{b}$ concentration did not change after any treatment. In general, the application of $\mathrm{I}^{-}$or $\mathrm{IO}_{3}{ }^{-}$did not exert significant changes in chlorophyll content, either with or without chitosan.

Table 5. Content of chlorophyll a, chlorophyll b, and total chlorophyll.

\begin{tabular}{|c|c|c|c|c|}
\hline \multirow{2}{*}{ Treatments } & \multirow{2}{*}{ Concentration (mg I kg ${ }^{-1}$ Substrate) } & \multicolumn{3}{|c|}{$\mathrm{mg} \mathrm{g}^{-1}$ Dry Weight $(\mathrm{n}=6)$} \\
\hline & & Chl a & Chl b & $\mathrm{Ct}$ \\
\hline $\mathrm{CsC}$ & 0 & $0.10 \mathrm{~b}$ & $0.05 \mathrm{~b}$ & $0.15 \mathrm{c}$ \\
\hline $\mathrm{Cs}-\mathrm{KIO}_{3}$ & 5 & $0.11 \mathrm{~b}$ & $0.09 \mathrm{ab}$ & $0.19 \mathrm{bc}$ \\
\hline $\mathrm{Cs}-\mathrm{KIO}_{3}$ & 25 & $0.10 \mathrm{~b}$ & $0.09 \mathrm{ab}$ & $0.19 \mathrm{bc}$ \\
\hline $\mathrm{Cs}-\mathrm{KIO}_{3} \mathrm{SDA}$ & 25 & $0.19 \mathrm{ab}$ & $0.12 \mathrm{ab}$ & $0.31 \mathrm{a}-\mathrm{c}$ \\
\hline $\mathrm{AC}$ & 0 & $0.18 \mathrm{ab}$ & $0.18 \mathrm{ab}$ & $0.36 \mathrm{a}-\mathrm{c}$ \\
\hline $\mathrm{KIO}_{3}$ & 5 & $0.28 \mathrm{a}$ & $0.19 \mathrm{ab}$ & $0.47 \mathrm{a}-\mathrm{c}$ \\
\hline $\mathrm{KIO}_{3}$ & 25 & $0.18 \mathrm{ab}$ & $0.33 \mathrm{a}$ & $0.51 \mathrm{a}-\mathrm{c}$ \\
\hline $\mathrm{KIO}_{3} \mathrm{SDA}$ & 25 & $0.32 \mathrm{a}$ & $0.24 \mathrm{ab}$ & $0.56 \mathrm{ab}$ \\
\hline $\mathrm{CsC}$ & 0 & $0.17 \mathrm{ab}$ & $0.12 \mathrm{ab}$ & $0.30 \mathrm{a}-\mathrm{c}$ \\
\hline Cs-KI & 5 & $0.25 \mathrm{ab}$ & $0.12 \mathrm{ab}$ & $0.36 \mathrm{a}-\mathrm{c}$ \\
\hline Cs-KI & 25 & $0.28 \mathrm{a}$ & $0.12 \mathrm{ab}$ & $0.39 a-c$ \\
\hline Cs-KI SDA & 25 & $0.28 \mathrm{a}$ & $0.31 \mathrm{ab}$ & $0.59 \mathrm{a}$ \\
\hline $\mathrm{AC}$ & 0 & $0.17 \mathrm{ab}$ & $0.17 \mathrm{ab}$ & $0.35 \mathrm{a}-\mathrm{c}$ \\
\hline KI & 5 & $0.11 \mathrm{~b}$ & $0.08 \mathrm{ab}$ & $0.19 \mathrm{bc}$ \\
\hline KI & 25 & $0.18 \mathrm{ab}$ & $0.09 \mathrm{ab}$ & $0.27 \mathrm{a}-\mathrm{c}$ \\
\hline KI SDA & 25 & $0.30 \mathrm{a}$ & $0.12 \mathrm{ab}$ & $0.42 \mathrm{a}-\mathrm{c}$ \\
\hline Concentration $(\mathrm{C})$ & & 0.038 & ns & ns \\
\hline Chitosan (Cs) & & ns & ns & ns \\
\hline Chemical Species (CSp) & & ns & ns & ns \\
\hline $\mathrm{C} \times \mathrm{Cs}$ & & ns & ns & ns \\
\hline $\mathrm{C} \times \mathrm{CSp}$ & & ns & ns & ns \\
\hline $\mathrm{Cs} \times \mathrm{CSp}$ & & 0.0035 & ns & 0.0089 \\
\hline $\mathrm{C} \times \mathrm{Cs} \times \mathrm{CSp}$ & & ns & ns & ns \\
\hline
\end{tabular}

Means with the same letter are statistically identical (LSD, $p \leq 0.05)$; sample size, $6(\mathrm{n}=6)$, ns, not significant. Chl a, chlorophyll a; Chl b, chlorophyll b; Ct, chlorophyll total. 


\subsection{Enzymatic Activity, Antioxidants, and Proteins}

No experimental treatment produced significant differences, compared to the chitosan and absolute controls, for superoxide dismutase (SOD), catalase (CAT), reduced glutathione (GSH), glutathione peroxidase (GPX), nor total antioxidant activity (Figure 3). It appears that iodine treatments did not directly either contribute to an increase or decrease in catalytic and antioxidant activity, presumably because there was no plant stress generated. However, total protein content (TP) increased considerably after KI treatments, both at low $\left(5 \mathrm{mg} \mathrm{I} \mathrm{kg}^{-1}\right)$ and high $\left(25 \mathrm{mg} \mathrm{I} \mathrm{kg}^{-1}\right)$ doses applied either once or as split dose.
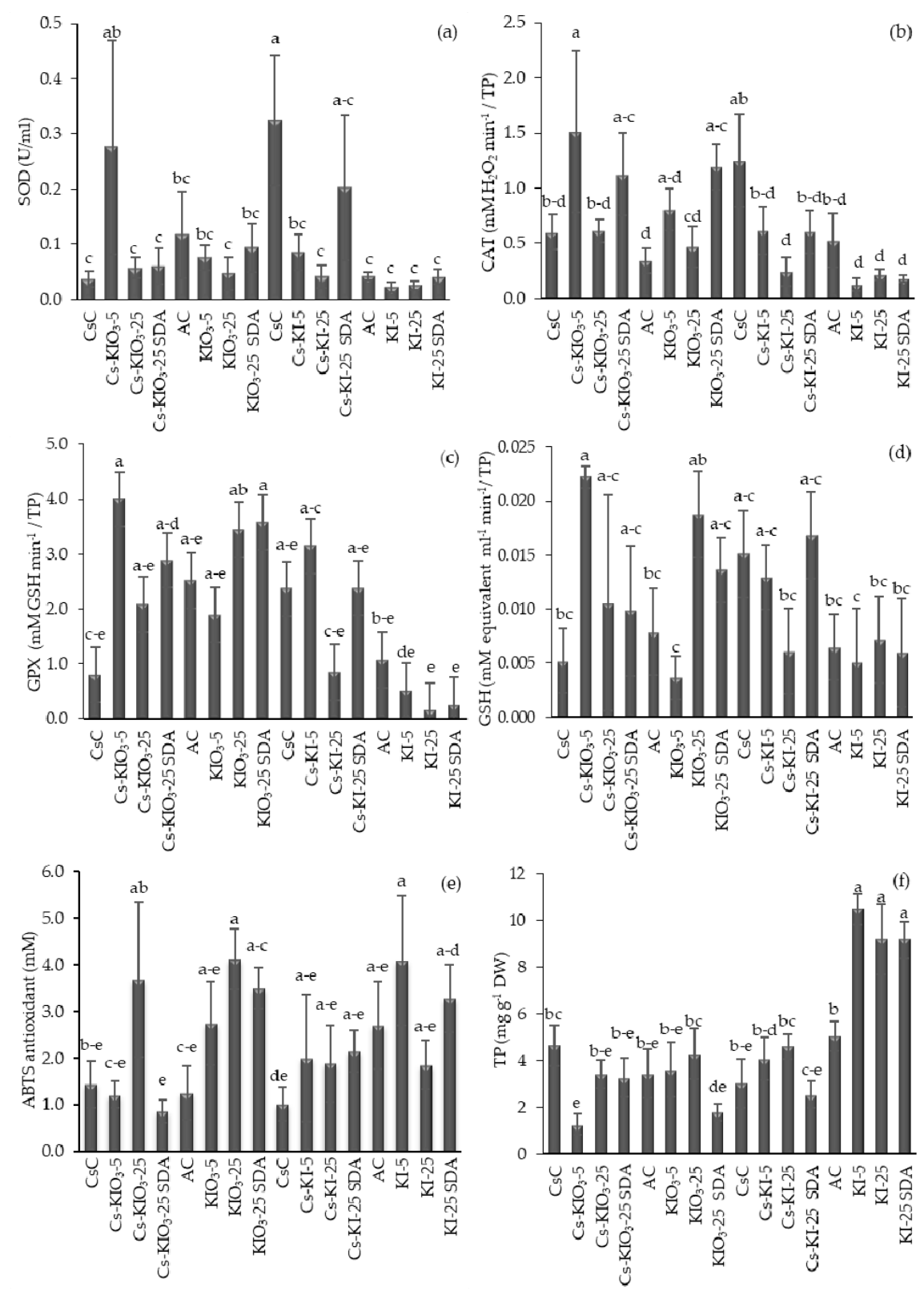

Figure 3. Changes in enzymatic, antioxidant, and protein content of lettuce after treatment with iodine and chitosan. (a) Superoxide dismutase, SOD; (b) catalase, CAT; (c) glutathione peroxidase, GPX; (d) reduced glutathione, GSH; (e) total antioxidant content; (f) total protein, TP. Means with the same letter are statistically identical (LSD, $p \leq 0.05)$; sample size, $6(n=6)$; the bars represent the standard error. Sample size was $6(n=6)$ for all measurements except SOD $(n=5)$. 
Despite the fact that there are differences in several enzymes in one factor or between factors detected in ANOVA, there is no enzyme activity that has been increased by any treatment.

\section{Discussion}

Four possible outcomes for iodine biofortification have been described: (1) it has a wholly negative impact on plant growth and other physiological and biochemical variables; (2) it has no effect on plants; (3) it has a wholly positive impact on plant growth and other physiological and biochemical variables; or (4) it has mixed positive and negative effects on plants [9,41-43]. With the exception of three specific treatment combinations, there were no changes in lettuce biomass. Something similar happened with the concentrations of mineral nutrients, which potentially indicates an ideal scenario where increases in iodine content do not antagonize the accumulation of other nutrients such as iron and zinc. Biofortification with iodine was achieved and we found greater concentrations after iodine treatments applied as two doses. The working hypothesis was that the presence of chitosan would augment the absorption of iodine in lettuce plants, but the results did not show any appreciable changes for treatments that included chitosan. There have only been two similar studies that investigate the uses of chitosan biopolymers with iodine, applied as thin films. One involved the application of Cs-KI films on tomato plants and found that it did not affect the antioxidant activity of the fruit [42]. The other applied edible films of $\mathrm{Cs}-\mathrm{KIO}_{3}$ to hot pepper and found that the iodine ion does not leach away due to the strong ionic interactions between the chitosan cationic groups and $\mathrm{IO}_{3}{ }^{-}$[7].

\subsection{Biomass Production and Yields}

With the exception of three treatment combinations, no impact on plant growth was found after iodine application. There were increases in LFW and LDW biomass following a single application of $\mathrm{Cs}-\mathrm{KIO}_{3}$, which were consistent with results from previous lettuce biofortification studies using $\mathrm{KIO}_{3}[10,15,44]$. Conversely, there were decreases in HFW and HDW biomass after SDA of Cs-KI, potentially due to the second application direct to the substrate at 15 d.a.t. and subsequent rapid absorption by the plant roots. In addition, there is a high correlation between LFW and LDW $(R=0.9)$.

The $\mathrm{I}^{-}$anion is known to have greater solubility in soil and better absorption by roots than its $\mathrm{IO}_{3}{ }^{-}$counterpart [44]. Reports of greater plant sensitivity to high doses of $\mathrm{KI}$ than to $\mathrm{KIO}_{3}$ applied to the substrate have been published $[15,45]$. At low doses $\left(0.013-0.129 \mathrm{mg} \mathrm{L}^{-1}\right)$, there are no toxic effects reported for either iodine species [45]. In hydroponic systems, lettuce has demonstrated greater sensitivity to $\mathrm{I}^{-}$. Phytotoxic effects from excessive iodine accumulation were seen at $\mathrm{I}^{-}$doses of $80 \mu \mathrm{M}$, while $\mathrm{IO}_{3}{ }^{-}$did not affect biomass at doses up to $240 \mu \mathrm{M}$ [10].

Considering those previous reports, the iodine concentrations utilized in the present work were well within the ranges used for lettuce cultivation. The best iodine species for biofortification is reportedly $\mathrm{IO}_{3}^{-}[12,13,43]$. Our study found that $\mathrm{Cs}-\mathrm{KIO}_{3}$ complexes (at 5 and $25 \mathrm{mg} \mathrm{I} \mathrm{kg}{ }^{-1}$ ) applied to the substrate led to biomass increases. Compared to KI, that iodine salt is less phytotoxic. Additionally, appropriate doses of chitosan have been found to stimulate plant growth, development, and yields $[24,46]$

The largest improvements to LFW, LDW, and HDW were seen after single applications of Cs- $\mathrm{KIO}_{3}$ (at 5 and $25 \mathrm{mg} \mathrm{I} \mathrm{kg}^{-1}$ ), rather than either $\mathrm{Cs}-\mathrm{KI}$ or $\mathrm{KIO}_{3}$. Based on those results, we believe that the complex of $\mathrm{Cs}$ and $\mathrm{IO}_{3}{ }^{-}$favor improvements in biomass, as there are also other studies that show that $\mathrm{Cs}$ and $\mathrm{IO}_{3}{ }^{-}$alone have positive effects on plant biomass $[9,22,47]$. Cs by itself is a good source of $\mathrm{C}, \mathrm{H}$, $\mathrm{O}$ and $\mathrm{N}$ for plants, it also works as a chelating agent for metals, which favors chelated elements that are available in assimilable forms for plants, and it has also been related for exercising its function as an elicitor, these and other Cs functions can contribute to plant growth [23,47]. On the other hand, $\mathrm{IO}_{3}{ }^{-}$is less phytotoxic than $\mathrm{I}^{-}$, as it must first be reduced to $\mathrm{I}^{-}$before it can be assimilated. Perhaps this step is a checkpoint for the plant's signaling processes. $\mathrm{IO}_{3}{ }^{-}$could also be acting as an elicitor. On the other hand, $\mathrm{I}^{-}$is rapidly assimilated by the plant, probably leading to greater accumulation in the chloroplasts while exerting its phytotoxic effects, which have been noted as chlorosis or biomass 
reductions $[10,15]$. However, the mechanisms of iodide and iodate root absorption have not yet been fully elucidated and little is known for sure about the subject $[48,49]$.

\subsection{Mineral Content}

There were significant changes between treatments in the concentrations of $\mathrm{N}, \mathrm{P}, \mathrm{K}, \mathrm{Ca}, \mathrm{Na}$, $\mathrm{Cu}, \mathrm{Fe}$ and $\mathrm{Zn}$. However, those changes were within the ranges seen for the absolute and chitosan controls and no other antagonistic effects between iodine and the mentioned minerals could be verified. Magnesium and manganese concentrations went up after single applications of Cs-KI ( 5 and $25 \mathrm{mg} \mathrm{I} \mathrm{kg}^{-1}$, respectively). In this study, we find significant positive correlations ( $\left.\mathrm{R} \geq 0.8\right)$ between $\mathrm{Ca}-\mathrm{Mg}, \mathrm{Mg}-\mathrm{Na}$ and $\mathrm{Ca}-\mathrm{Na}$.

Soil application of fertilizers containing KI $\left(0.5,1.0\right.$, and $\left.2.0 \mathrm{~kg} \mathrm{I} \mathrm{ha}^{-1}\right)$ reportedly led to increases in $\mathrm{Ca}, \mathrm{Mg}, \mathrm{Mn}$, and Cd levels in lettuce [11]. Similarly, levels of $\mathrm{Mg}, \mathrm{Mn}$, and $\mathrm{Cu}$ in tomato leaves and stems increased with application of KI solutions (4-100 $\mathrm{mg} \mathrm{I} \mathrm{kg}^{-1}$ ), although iron levels fell [50]. The authors attribute those results to the changes in redox equilibrium causes by iodine during cultivation. Increases in $\mathrm{Mn}$ and $\mathrm{Cu}$ concentrations in prickly pear cactus have been seen following KI $\left(10^{-4} \mathrm{~mol} \mathrm{dm}^{-3}\right)$ application, as well as $\mathrm{P}$ and $\mathrm{Mg}$ increases after $\mathrm{KIO}_{3}\left(10^{-4} \mathrm{~mol} \mathrm{dm}{ }^{-3}\right)$ application via fertigation [51]. Conversely, negative correlations have been seen for $\mathrm{K}, \mathrm{Mg}, \mathrm{Ca}, \mathrm{S}, \mathrm{Na}, \mathrm{B}, \mathrm{Cu}, \mathrm{Fe}$, $\mathrm{Mn}, \mathrm{Zn}, \mathrm{Cd}$ and $\mathrm{Pb}$ content after fertilization with either $\mathrm{KI}_{\text {or }} \mathrm{KIO}_{3}$ [14]. In the present study, there were no negative correlations seen in the evaluated minerals after $\mathrm{I}^{-}$or $\mathrm{IO}_{3}{ }^{-}$application, either with or without chitosan.

\subsection{Iodine Content in Lettuce}

Even though iodine is not considered an essential nutrient for plants, several investigations have shown that the right doses of iodine can improve yields and that it is translocated to diverse tissues within the plant. Maximum concentrations of iodine were seen following application of $\mathrm{KIO}_{3}$ $\left(25 \mathrm{mg} \mathrm{I} \mathrm{kg}^{-1}\right)$ as a split dose. Possibly, iodine was rapidly absorbed by the roots due to the direct application to the substrate. Some authors have suggested that biofortification is most successfully with $\mathrm{IO}_{3}{ }^{-}$as it does not have phytotoxic effects and the biomass either increases or is not negatively affected [12,47,52].

Regarding the original question of whether Cs-KI or Cs- $\mathrm{KIO}_{3}$ complexes would increase iodine absorption, neither complex had an outstanding impact on iodine content when compared to the treatments without chitosan. For example, for $\mathrm{I}^{-}$, the plant response was similar after single application treatments with and without Cs. The greatest concentrations were after SDA of KI treatments, even those changes were not significant. In contrast, $\mathrm{KIO}_{3}$ and its $\mathrm{Cs}$ complexed form induced significant differences in iodine concentrations after two applications. Of the two forms, the $\mathrm{KIO}_{3}$ alone led to a greater increase in iodine concentration. There are two potential explanations for these results. One, in order to be absorbed $\mathrm{IO}_{3}{ }^{-}$must first be reduced to $\mathrm{I}^{-}$, a process that is carried out by iodate reductase enzymes [53]. So, when $\mathrm{IO}_{3}{ }^{-}$is complexed with Cs, the reduction process takes longer than when the free salt is applied and thus it becomes bioavailable slower. Two, the $\mathrm{Cs}-\mathrm{KIO}_{3}$ may become fixed in the ground, not volatilizing, which means crops with short cultivation cycles, like lettuce, would be unable to fully take advantage of its presence. Both $\mathrm{I}^{-}$and $\mathrm{IO}_{3}{ }^{-}$applied to soil are converted to organic iodine after only 14 days, and in that form become fixed in the ground and less readily soluble in water [54]. This could explain why there was no significant difference between $\mathrm{I}^{-}$and $\mathrm{IO}_{3}{ }^{-}$ applied in a single treatment, with and without Cs, at either concentration ( 5 or $\left.25 \mathrm{mg} \mathrm{I} \mathrm{kg}^{-1}\right)$.

Several authors have reported high concentrations of iodine after biofortification with $\mathrm{KIO}_{3}[15,55]$. Conversely, iodine content in lettuce after biofortification with high doses of iodide during two trials (summer and winter) was up to five times higher than with iodate. The iodine concentrations of inner and outer leaves reached 653 and $764 \mu \mathrm{g} \mathrm{I} \mathrm{kg}{ }^{-1}$, respectively [45]. Doses of iodine below $2.5 \mathrm{mg} \mathrm{I} \mathrm{kg}^{-1}$ have no effect on biomass [55,56], while at times doses between 5 and $25 \mathrm{mg} \mathrm{I} \mathrm{kg}^{-1}$ applied to soil have been found to not affect yields $[57,58]$. Those previously reported results are consistent with the 
findings of the present study, with the exception of the SDA of Cs-KI $\left(25 \mathrm{mg} \mathrm{I} \mathrm{kg}^{-1}\right)$ which ended up reducing biomass.

\subsection{Phenol Content}

This study found an increase in cell wall-bound phenols after application of $\mathrm{IO}_{3}{ }^{-}\left(25 \mathrm{mg} \mathrm{I} \mathrm{kg}^{-1}\right)$, either in single dose or SDA, when compared to the absolute controls. The lack of changes in phenol concentrations may indicate that no oxidative stress was induced in the plants following treatment, except for the case of the treatments mentioned. In those cases, the action of cell wall-bound phenols could have potentially impeded iodine oxidation, which could be why no increases in free phenols were seen. Substrate and foliar applications of $\mathrm{I}^{-}$or $\mathrm{IO}_{3}{ }^{-}$, either at $1 \mu \mathrm{M}$ daily or $100 \mu \mathrm{M}$ every two weeks, were not found to significantly affect phenol concentrations in tomato seedlings (var. Rio Grande) [35]. Similarly, in chili pepper covered with edible films of $\mathrm{Cs}_{-} \mathrm{IO}_{3}$, no changes in total phenol content were seen for either the controls or the treated peppers [7]. On the other hand, tomatoes coated with chitosan-iodine films demonstrated greater antioxidant activity and total phenol content than uncoated fruit [42].

\subsection{Chlorophyll Content}

Little is known about the mechanisms of iodine toxicity or transport within plants. What is known, however, is that $\mathrm{I}^{-}$toxicity is a consequence of intracellular oxidation or electron loss turning it into molecular iodine, which can bind to cellular components including chlorophyll [58]. In this study, the applied doses of iodide and iodate did not cause changes in chlorophyll content compared to the controls. Total chlorophyll has a high correlation with $\mathrm{Chl}$ a and $\mathrm{Chl} \mathrm{b}$ and likewise $\mathrm{Chl}$ a and $\mathrm{Chl} b$ $(\mathrm{R} \geq 0.7)$. Similarly, other authors have reported insignificant changes in the contents of photosynthetic pigments [59,60]. Chitosan, on the other hand, applied in concentrations of $0.10 \%, 0.15 \%, 0.20 \%$, and $0.30 \%$ has been observed to increase the index of chlorophyll content in lettuce leaves from 29.8 to $34.4,35.5,37.5$, and 41.4, respectively [24]. Iodide does not inhibit chlorophyll synthesis, but it is known to reduce photosynthetic activity [59]. Nonetheless, chloroplasts are known major sites of ROS production [60]. It would appear that at the doses used in this study, iodide and iodate did not significantly affect the chlorophyll content of lettuce.

\subsection{Total Protein Content}

Treatments with KI were the only treatments that led to increases in total protein content. Those increases may be due to the fact that $\mathrm{KI}$ is more readily assimilated, potentially leading to the production of secondary metabolites and the concomitant production of the proteins necessary for that metabolism. Moreover, the amount of total proteins has a highly significant negative correlation $(R \geq 0.8)$ with the enzymatic activity of GSH and GPX. Previous works have also observed significant increases in total protein content, although those treatments used $\mathrm{IO}_{3}{ }^{-}$, with maximum protein concentrations reached at doses of $80 \mu \mathrm{M}$ iodine [61].

\subsection{Enzymatic and Antioxidant Activity}

There were no significant differences observed in enzymatic activity after any treatments. Once again, it was demonstrated that the applied doses of iodine did not induce a defensive response in lettuce. There are high positive correlations $(R \geq 0.5)$ between enzymatic activities of GSH-GPX, CAT-GPX, and CAT-GSH that we believe have to do with maintaining a balance at the cellular level. There are no high and significant correlations between enzyme and antioxidant activities, with the exception of SOD and wall-linked phenols where there is a low but significant correlation. The latter we can attribute it to the fact that SOD heads the first line of defense of enzymatic activity and its correlation with phenols linked to the wall, we perceive it as a redox or neutralization mechanism against high concentration $\mathrm{IO}_{3}{ }^{-}$salts. Conversely, some authors have reported increases in enzymatic activity following biofortification with iodine. During soilless cultivation of lettuce, SOD was reduced 
after application of $\mathrm{I}^{-}$at 20, 40, and $80 \mu \mathrm{M}$, while $\mathrm{IO}_{3}{ }^{-}$led to its increase in doses greater than $40 \mu \mathrm{M}$. Ascorbate peroxidase (APX) activity increased with $\mathrm{IO}_{3}{ }^{-}$application at any dose, while CAT activity also increased with $\mathrm{IO}_{3}{ }^{-}$as well as $\mathrm{I}^{-}$application, reaching its maximum value at $\mathrm{IO}_{3}{ }^{-}$doses $\geq 80 \mu \mathrm{M}$ [43]. Similarly, hydroponic lettuce grown under salt stress and biofortified with $\mathrm{IO}_{3}{ }^{-}$had increased activities of SOD, APX, Dehydroascorbate reductase (DHAR), and Glutathione reductase (GR) [12]. Soybeans grown under $\mathrm{Cd}^{2+}$ stress and biofortified with $\mathrm{IO}_{3}{ }^{-}$at various concentrations (20, 40 , and $80 \mu \mathrm{M}$ ) demonstrated increased SOD, APX, and GR activity [62]. Tomato biofortified with $\mathrm{I}^{-}$or $\mathrm{IO}_{3}{ }^{-}$, applied to soil or foliage, either daily $(1 \mu \mathrm{M})$ or biweekly $(100 \mu \mathrm{M})$, had reduced SOD activity following the biweekly $\mathrm{I}^{-}$treatments and the daily, foliar treatments of either iodine salt. However, the daily application of foliar $\mathrm{I}^{-}$led to increases in the concentrations of non-enzymatic antioxidants, namely ascorbate (22\%) and glutathione (85\%) [35].

Plants have evolved several antioxidant systems to help them avoid damage from oxidative stress. One of those systems involves the enzymes SOD, CAT, and APX, acting in that order. SOD reduces $\mathrm{O}_{2}^{-}$to $\mathrm{H}_{2} \mathrm{O}_{2}$, which in turn is a substrate for CAT, APX, and other enzymes [60]. Iodide is considered an inorganic antioxidant that reacts with ROS (ozone, singlet oxygen, and superoxide) at rates 12 to 500 times those of ascorbate and glutathione [63]. In aquatic plants of the genus Laminaria, the enzyme haloperoxidase catalyzes the oxidation of iodide to hypoiodous acid and molecular iodine in the presence of $\mathrm{H}_{2} \mathrm{O}_{2}$ [64].

The results of the present work differed from those previously reported, although that could be attributed to a number of factors. For example, in this study, cultivation was substrate-based while previous reports have used hydroponic systems [43]. Additionally, the accumulation of iodine and other biomolecules can depend on factors such as the dose and species of iodine applied, the plant species, and the type of application, be it foliar or directly to the substrate, all of which can lead to the differential accumulation of iodine [15].

\section{Conclusions}

The biofortification of lettuce using complexes of chitosan with $\mathrm{KI}$ or $\mathrm{KIO}_{3}$ (Cs-KI and Cs- $\mathrm{KIO}_{3}$ ) did not induce negative effects on the mineral content, chlorophyll content, enzymatic activity, antioxidant content, nor the phenol content of lettuce. Moreover, $\mathrm{Cs}_{-} \mathrm{KIO}_{3}$, either at $5 \mathrm{mg} \mathrm{I} \mathrm{kg}^{-1}$ or $25 \mathrm{mg} \mathrm{I} \mathrm{kg}^{-1}$, applied prior to transplanting increased plant biomass and led to iodine levels of 6.4 and $23.1 \mathrm{mg} \mathrm{I} \mathrm{kg}^{-1}$ dry weight, respectively. Plant biomass was reduced after split-dose application (SDA) of Cs-KI before and after transplanting. The manner of treatment application as a split dose before and after transplant was a determining factor for greater iodine accumulation. Application before and after transplanting of $\mathrm{KIO}_{3}$ led to the highest iodine concentrations (103.2 mg I kg-1 dry weight), although biomass was considerably reduced compared to single applications of $\mathrm{Cs}-\mathrm{KIO}_{3}$ at either concentration ( 5 or $25 \mathrm{mg} \mathrm{I} \mathrm{kg}^{-1}$ ). Although $\mathrm{Cs}-\mathrm{KI}$ and $\mathrm{Cs}-\mathrm{KIO}_{3}$ did not increase iodine absorption compared to the free salts, in some cases they caused increases in biomass while maintaining levels of iodine accumulation in lettuce leaves. As far as we know, there are no similar reports on crop biofortification with chitosan-iodine complexes applied to either soil or substrate. Further biofortification studies with chitosan-iodine complexes in crop species other than lettuce are required in order to evaluate the effects they may have when treatment times are longer.

Author Contributions: I.E.D.R., experimentation, chemical analysis, analysis of data and draft writing; H.O.O., design of experiments and synthesis of Cs complexes; L.I.T.T., design of experiments and chemical analysis; A.J.M., methodology, experimentation; S.G.M., methodology, experimentation; B.C.G., chemical analysis; M.C.D.1.F., data analysis; A.B.M., conceptualization, methodology, data analysis. All authors were responsible for review and editing. All authors have read and agreed to the published version of the manuscript.

Funding: This research did not receive external funding.

Acknowledgments: Special thanks go to Laura Olivia Fuentes Lara and Carlos Alberto Arevalo SanMiguel from the UAAAN Department of Animal Nutrition for their support in mineral determination. Also, to Álvaro Morelos Moreno from the UAAAN Department of Horticulture for his help in determining the greenhouse climate conditions. 
Conflicts of Interest: The authors declare no conflict of interest.

\section{References}

1. de Benoist, B.; McLean, E.; Anderson, M.; Rogers, L. Iodine deficiency in 2007: Global progress since 2003. Food Nutr. Bull. 2008, 29, 195-202. [CrossRef] [PubMed]

2. WHO/UNICEF/ICCIDD. Recommended Iodine Levels in Salt and Guidelines for Monitoring their Adequacy and Effectiveness. In Proceedings of the Joint WHO Consultation, Geneva, Switzerland, 8-9 July 1996.

3. Pennington, J.A.T. A Review of Iodine Toxicity Reports. J. Am. Diet. Assoc. 1990, 90, 1571-1581.

4. Backer, H.; Hollowell, J. Use of iodine for water disinfection: Iodine toxicity and maximum recommended dose. Environ. Health Perspect. 2000, 108, 679-684. [CrossRef] [PubMed]

5. WHO/UNICEF/ICCIDD. Assessment of Iodine Deficiency Disorders and Monitoring Their Elimination; WHO Press: Geneva, Switzerland, 2007; ISBN 9789241595827.

6. Longvah, T.; Toteja, G.S.; Bulliyya, G.; Raghuvanshi, R.S.; Jain, S.; Rao, V.; Upadhya, A. Stability of added iodine in different Indian cooking processes. Food Chem. 2012, 130, 953-959. [CrossRef]

7. Limchoowong, N.; Sricharoen, P.; Konkayan, M.; Chanthai, S. A Simple Efficient and Economic Method for Obtaining Iodate-Rich Chili Pepper Based Chitosan Edible Thin Film. J. Food Sci. Technol. 2018, 55, 3263-3272. [CrossRef] [PubMed]

8. Reduce the Consumption of Salt. Available online: https://www.who.int/cardiovascular_diseases/es/ (accessed on 6 June 2019).

9. Medrano, J.; Leija, P.; González, S.; Juárez, A.; Benavides, A. Use of Iodine to Biofortify and Promote Growth and Stress Tolerance in Crops. Front. Plant Sci. 2016, 7, 1-20.

10. Blasco, B.; Rios, J.J.; Cervilla, L.M.; Sánchez, E.; Ruiz, J.M.; Romero, L. Iodine Biofortification and Antioxidant Capacity of Lettuce: Potential Benefits for Cultivation and Human Health. Ann. Appl. Biol. 2008, 152, 289-299. [CrossRef]

11. Smoleń, S.; Rozek, S.; Ledwozyw-Smoleń, I.; Strzetelski, P. Preliminary evaluation of the influence of soil fertilization and foliar nutrition with iodine on the efficiency of iodine biofortification and chemical composition of lettuce. J. Elem. 2011, 16, 613-622. [CrossRef]

12. Leyva, R.; Sánchez-Rodríguez, E.; Ríos, J.J.; Rubio-Wilhelmi, M.M.; Romero, L.; Ruiz, J.M.; Blasco, B. Beneficial Effects of Exogenous Iodine in Lettuce Plants Subjected to Salinity Stress. Plant Sci. 2011, 181, $195-202$. [CrossRef]

13. Kiferle, C.; Gonzali, S.; Holwerda, H.T.; Ibaceta, R.R.; Perata, P. Tomato fruits: A good target for iodine biofortification. Front. Plant Sci. 2013, 4, 1-10. [CrossRef]

14. Smoleń, S.; Skoczylas, Ł.; Rakoczy, R.; Ledwożyw-Smoleń, I.; Kopeć, A.; Piątkowska, E.; Bieżanowska-Kopeć, R.; Pysz, M.; Koronowicz, A.; Kapusta-Dutch, J.S.W. Mineral composition of field-grown Lettuce (Lactuca sativa L.) depending on the diversified fertilization with iodine and selenium compounds. Acta Sci. Pol. Hortorum Cultus 2015, 14, 97-114.

15. Lawson, P.G.; Daum, D.; Czauderna, R.; Meuser, H.; Härtling, J.W. Soil versus foliar iodine fertilization as a biofortification strategy for field-grown vegetables. Front. Plant Sci. 2015, 6, 1-11. [CrossRef] [PubMed]

16. Herrett, R.A.; Hatfield, H.H.; Crosby, D.G.; Vlitos, A.J. Leaf Abscission Induced by the Iodide Ion. Plant Physiol. 1962, 37, 358-363. [CrossRef] [PubMed]

17. Landini, M.; Gonzali, S.; Perata, P. Iodine biofortification in tomato. J. Plant Nutr. Soil Sci. 2011, 174, 480-486. [CrossRef]

18. Whitehead, D.C. The Influence of Organic Matter, Chalk, and Sesquioxides on the Solubility of Iodide, Elemental Iodine, and Iodate Incubated With Soil. J. Soil Sci. 1974, 25, 461-470. [CrossRef]

19. Shetaya, W.H.; Young, S.D.; Watts, M.J.; Ander, E.L.; Bailey, E.H. Iodine dynamics in soils. Geochim. Cosmochim. Acta 2012, 77, 457-473. [CrossRef]

20. Whitehead, D.C. The distribution and transformations of iodine in the environment. Environ. Int. 1984, 10, 321-339. [CrossRef]

21. Walker, M.; Ryan, C.A. Proteinase Inhibitor Synthesis in Tomato Leaves. Plant Physiol. 1984, 76, 787-790. [CrossRef]

22. Pichyangkura, R.; Chadchawan, S. Biostimulant activity of chitosan in horticulture. Sci. Hortic. (Amst.) 2015, 196, 49-65. [CrossRef] 
23. Malerba, M.; Cerana, R. Chitosan effects on plant systems. Int. J. Mol. Sci. 2016, 17, 996. [CrossRef]

24. Xu, C.; Mou, B. Chitosan as soil amendment affects lettuce growth, photochemical efficiency, and gas exchange. Horttechnology 2018, 28, 476-480. [CrossRef]

25. Kurukji, D.; Norton, I.; Spyropoulos, F. Fabrication of sub-micron protein-chitosan electrostatic complexes for encapsulation and pH-Modulated delivery of model hydrophilic active compounds. Food Hydrocoll. 2016, 53, 249-260. [CrossRef]

26. Kurita, K.; Sannan, T.; Iwakura, Y. Studies on chitin. VI. Binding of metal cations. J. Appl. Polym. Sci. 1979, 23, 511-515. [CrossRef]

27. Moulay, S. Molecular iodine/polymer complexes. J. Polym. Eng. 2013, 33, 389-443. [CrossRef]

28. Bocanegra, M.P.; Lobartini, J.C.; Orioli, G.A. Plant uptake of iron chelated by humic acids of different molecular weights. Commun. Soil Sci. Plant Anal. 2006, 37, 239-248. [CrossRef]

29. Chandra, S.; Chakraborty, N.; Dasgupta, A.; Sarkar, J.; Panda, K.; Acharya, K. Chitosan nanoparticles: A positive modulator of innate immune responses in plants. Sci. Rep. 2015, 5, 1-14. [CrossRef]

30. Horwitz, W. Official Methods of Analysis of the Association of Official Analytical Chemists, 15th ed.; AOAC International: Washington, DC, USA, 1971; ISBN 0935584145.

31. Fick, K.R.; Miller, S.M.; Funk, J.D.; McDowell, L.R.; Houser, R.H. Methods of Mineral Analysis for Plant and Animal Tissues; Universidad de Florida: Gainesville, FL, USA, 1976.

32. Fischer, P.W.; L'Abbé, M.R.; Giroux, A. Colorimetric determination of total iodine in foods by iodide-catalyzed reduction of Ce+4. J. Assoc. Off. Anal. Chem 1986, 69, 687-689. [CrossRef]

33. Cortés, C.; Rodríguez, M.N.; Benavides, A.; García, J.L.; Tornero, M.; Sánchez, P. Iodine increases growth and mineral concentration in bell pepper seedlings. Agrociencia 2016, 50, 747-758.

34. Munira, S.; Hossain, M.; Zakaria, M.; Ahmed, J.; Islam, M. Evaluation of Potato Varieties against Salinity Stress in Bangladesh. Int. J. Plant Soil Sci. 2015, 6, 73-81. [CrossRef]

35. Medrano, J.; Leija, P.; Juárez, A.; Rocha, A.; Benavides, A. Effect of iodine application on antioxidants in tomato seedlings. Rev. Chapingo Ser. Hortic. 2016, 22, 133-143.

36. Bradford, M.M. Determinación de proteínas: método de bradford. Anal. Biochem. 1976, 254, $248-254$. [CrossRef]

37. Gurr, S.I.; McPherson, J.; Bowles, D.J. Lignin and associated phenolic acids in cell walls. Mol. Plant Pathol. Pr. Approach 1992, 3, 62.

38. Cansev, A.; Gulen, H.; Eris, A. The activities of catalase and ascorbate peroxidase in olive (Olea europaea L. cv. Gemlik) under low temperature stress. Hortic. Environ. Biotechnol. 2011, 52, 113-120. [CrossRef]

39. Xue, T.; Hartikainen, H.; Piironen, V. Antioxidative and growth-promoting effect of selenium on senescing lettuce. Plant Soil 2001, 237, 55-61. [CrossRef]

40. Martínez, R.M.; Tuya, L.C.; Martínez, M.; Pérez, A.; Cánovas, A.M. The correlation coefficient of the spearman characterization ranges. Rev. Habanera Ciencias Medicas 2009, 8.

41. Kopeć, A.; Piatkowska, E.; Biezanowska-Kopeć, R.; Pysz, M.; Koronowicz, A.; Kapusta-Duch, J.; Smoleń, S.; Rakoczy, R.; Skoczylas, Ł.; Leszczyńska, T.; et al. Effect of lettuce biofortified with iodine by soil fertilization on iodine concentration in various tissues and selected biochemical parameters in serum of Wistar rats. J. Funct. Foods 2015, 14, 479-486. [CrossRef]

42. Limchoowong, N.; Sricharoen, P.; Techawongstien, S.; Chanthai, S. An iodine supplementation of tomato fruits coated with an edible film of the iodide-doped chitosan. Food Chem. 2016, 200, 223-229. [CrossRef]

43. Blasco, B.; Ríos, J.J.; Leyva, R.; Cervilla, L.M.; Sánchez-Rodríguez, E.; Rubio-Wilhelmi, M.M.; Rosales, M.A.; Ruiz, J.M.; Romero, L. Does iodine biofortification affect oxidative metabolism in lettuce plants. Biol. Trace Elem. Res. 2011, 142, 831-842. [CrossRef]

44. Hu, Q.; Moran, J.E.; Blackwood, V. Geochemical Cycling of Iodine Species in Soils. Lawrence Livermore Natl. Lab.(LLNL): Livermore 2007.

45. Voogt, W.; Holwerda, H.T.; Khodabaks, R. Biofortification of lettuce (Lactuca sativa L.) with iodine: The effect of iodine form and concentration in the nutrient solution on growth, development and iodine uptake of lettuce grown in water culture. J. Sci. Food Agric. 2010, 90, 906-913.

46. Wang, M.; Chen, Y.; Zhang, R.; Wang, W.; Zhao, X.; Du, Y.; Yin, H. Effects of chitosan oligosaccharides on the yield components and production quality of different wheat cultivars (Triticum aestivum L.) in Northwest China. F. Crop. Res. 2015, 172, 11-20. [CrossRef] 
47. El Hadrami, A.; Adam, L.R.; El Hadrami, I.; Daayf, F. Chitosan in Plant Protection. Mar. Drugs 2010, 8, 968-987. [CrossRef] [PubMed]

48. Cakmak, I.; Prom-u-thai, C.; Guilherme, L.R.G.; Rashid, A.; Hora, K.H.; Yazici, A.; Savasli, E.; Kalayci, M.; Tutus, Y.; Phuphong, P.; et al. Iodine biofortification of wheat, rice and maize through fertilizer strategy. Plant Soil 2017, 418, 319-335. [CrossRef]

49. Leija, P.; Benavides, A.; Rocha, A.; Medrano, J.R. Biofortification with iodine in plants for human consumption. Rev. Mex. Ciencias Agrícolas 2017, 7, 2025.

50. Hageman, R.H.; Hodge, E.S.; McHargue, J.S. Effect of Potassium Iodide on the Ascorbic Acid Content and Growth of Tomato Plants. Plant Physiol. 1942, 17, 465-472. [CrossRef]

51. García Osuna, H.T.; Benavides Mendoza, A.; Rivas Morales, C.; Morales Rubio, E.; Verde Star, J.; Miranda Ruvalcaba, R. Iodine application increased ascorbic acid content and modified the vascular tissue in Opuntia Ficus-Indica L. Pakistan J. Bot. 2014, 46, 127-134.

52. Blasco, B.; Leyva, R.; Romero, L.; Ruiz, J.M. Iodine effects on phenolic metabolism in lettuce plants under salt stress. J. Agric. Food Chem. 2013, 61, 2591-2596. [CrossRef]

53. Kato, S.; Wachi, T.; Yoshihira, K.; Nakagawa, T.; Ishikawa, A.; Takagi, D.; Tezuka, A.; Yoshida, H.; Yoshida, S.; Sekimoto, H.; et al. Rice (Oryza sativa L.) roots have iodate reduction activity in response to iodine. Front. Plant Sci. 2013, 4, 1-12. [CrossRef]

54. Takeda, A.; Tsukada, H.; Takahashi, M.; Takaku, Y.; Hisamatsu, S. Changes in the chemical form of exogenous iodine in forest soils and their extracts. Radiat. Prot. Dosimetry 2015, 167, 181-186. [CrossRef]

55. Dai, J.L.; Zhu, Y.G.; Huang, Y.Z.; Zhang, M.; Song, J.L. Availability of iodide and iodate to spinach (Spinacia oleracea L.) in relation to total iodine in soil solution. Plant Soil 2006, 289, 301-308. [CrossRef]

56. Smolen, S.; Kowalska, I.; Sady, W. Assessment of biofortification with iodine and selenium of lettuce cultivated in the NFT hydroponic system. Sci. Hortic. (Amst.) 2014, 166, 9-16. [CrossRef]

57. Hong, C.L.; Weng, H.X.; Qin, Y.C.; Yan, A.L.; Xie, L.L. Transfer of iodine from soil to vegetables by applying exogenous iodine. Agron. Sustain. Dev. 2008, 28, 575-583. [CrossRef]

58. Dai, J.L.; Zhu, Y.G.; Zhang, M.; Huang, Y.Z. Selecting iodine-enriched vegetables and the residual effect of iodate application to soil. Biol. Trace Elem. Res. 2004, 101, 265-276. [CrossRef]

59. Mynett, A.; Wain, R.L. Herbicidal Action of Iodide: Effect on Chlorophyll Content and Photosynthesis in Dwarf Bean Phaseolvs Vulgaris. Weed Res. 1973, 13, 101-109. [CrossRef]

60. Gill, S.S.; Tuteja, N. Reactive oxygen species and antioxidant machinery in abiotic stress tolerance in crop plants. Plant Physiol. Biochem. 2010, 48, 909-930. [CrossRef]

61. Blasco, B.; Rios, J.J.; Cervilla, L.M.; Sánchez-Rodríguez, E.; Rubio-Wilhelmi, M.M.; Rosales, M.A.; Ruiz, J.M.; Romero, L. Photorespiration Process and Nitrogen Metabolism in Lettuce Plants (Lactuca sativa L.): Induced Changes in Response to Iodine Biofortification. J. Plant Growth Regul. 2010, 29, 477-486. [CrossRef]

62. Gupta, N.; Bajpai, M.; Majumdar, R.; Mishra, P. Response of iodine on antioxidant levels of Glycine max L. Grown under Cd2+ stress. Adv. Biol. Res. (Rennes) 2015, 9, 40-48.

63. Küpper, F.C.; Carpenter, L.J.; McFiggans, G.B.; Palmer, C.J.; Waite, T.J.; Boneberg, E.M.; Woitsch, S.; Weiller, M.; Abela, R.; Grolimund, D.; et al. Iodide accumulation provides kelp with an inorganic antioxidant impacting atmospheric chemistry. Proc. Natl. Acad. Sci. USA 2008, 105, 6954-6958.

64. Küpper, F.; Schweigert, N.; Gall, E.A.; Legendre, J.; Vilter, H.; Kloareg, B. Iodine uptake in Laminariales involves extracellular, haloperoxidase-mediated oxidation of iodide. Planta 1998, 207, 163-171. [CrossRef]

(C) 2020 by the authors. Licensee MDPI, Basel, Switzerland. This article is an open access article distributed under the terms and conditions of the Creative Commons Attribution (CC BY) license (http://creativecommons.org/licenses/by/4.0/). 